\author{
Ivana Čapeta Rakić
}

Odsjek za povijest umjetnosti, Filozofski fakultet Sveučilišta u Splitu

\title{
Ponzonijevih deset slika u svodu glavnog oltara splitske katedrale: razmatranja o stilsko-oblikovnim svojstvima, izvornoj funkciji i ikonografsko-ikonološkom aspektu
}

\author{
Prethodno priopćenje - Preliminary communication \\ Primljeno - Received 6. 5. 2018. \\ UDK 75Ponzoni, $\mathrm{M}$.
}

DOI 10.31664/ripu.2018.42.09

\begin{abstract}
Sažetak
U članku se donose nove hipoteze o stilsko-oblikovnim svojstvima $i$ izvornoj funkciji Ponzonijevih deset slika na platnu, koje su izmedu 1682. i 1689. godine umetnute u drveni, kasetirani svod glavnog oltara splitske katedrale, a nastale su pedesetak godina ranije. Na temelju materijalnih ukaza i interpretacije već objavljenih arhivskih podataka autorica predlaže izvorni oblik slikarske cjeline kao jedinstvenog poliptiha u funkciji pokrovne pale (pale feriale) za veliku srebrnu gotičku palu Ivana Gerardova iz Pesara. Hipotezu autorica potkrepljuje srodnim
\end{abstract}

poredbenim primjerima unutar jadranskog bazena. Također razrađuje ikonografsko-ikonološki aspekt slikarske cjeline, koji je po svoj prilici osmišljen kao vizualno didaktičko sredstvo u službi propovijedi s nizom euharistijskih egzempla i njihovih starozavjetnih prefiguracija koje su trebale poduprijeti nauk o transsupstancijaciji. Narudžbu ovog složenog ikonografskog niza autorica povezuje s pojačanom potrebom posttridentinske crkve u osnaživanju kršćanske vjere zbog vjerskih i političkih previranja u splitskoj nadbiskupiji tijekom 17. stoljeća.

Ključne riječi: Split, Matteo Ponzoni (Ponzone, Pončun), Sforza Ponzoni (Ponzone), srednji vijek, egzempla, 17. stoljeće, ikonografija, ikonologija, euharistija, protestantizam

U dosadašnjoj je povijesnoumjetničkoj historiografiji opće prihvaćeno da je autor ciklusa od deset slika na platnu, koje se nalaze u svodu iznad glavnog oltara splitske katedrale, mletački slikar Matteo Ponzoni (Ponzone, Pončun; Venecija, 1583. - 1663./1675.). Kritika je podjednako suglasna da su slike vjerojatno nastale između 1635. i 1640. godine (premda su mogle nastati i nešto ranije $)^{1}$ te da su od vremena Cosmijevih zahvata u katedrali, po svoj prilici između 1682. i 1689. godine, premještene u kasetirani, pozlaćeni svod, gdje ih i danas vidimo ${ }^{2}$ (sl. 1). Istodobno su se oblik izvorne slikarske cjeline, njezina namjena i smještaj unutar splitske katedrale našli pod upitnikom, s obzirom na to da su, kronološki gledano, slike prethodile konstrukciji drvenoga svoda za gotovo pedeset godina. ${ }^{3}$ Ikonografski i ikonološki aspekt pojedinačnih slikarskih epizoda, kao i njihova cjelovita interpretacija u kontekstu vremena nastanka, također se nisu razmatrali dalje od kratkih deskripcija pojedinačnih prizora koje je identificirao još Kruno Prijatelj u sedamdesetim godinama minulog stoljeća, nakon tadašnjih zahvata nji- hove obnove. ${ }^{4}$ Bitan pomak prema rasvjetljavanju mogućeg izvornog izgleda i smještaja Ponzonijevih slika, koje su ovdje u žarištu interesa, donijela je u višekratnim prezentacijama i objavljenim člancima Žana Matulić Bilač, razmatrajući ih u širem kontekstu povijesnih preinaka svetišta splitske katedrale. ${ }^{5}$ Nepobitni fizički i materijalni ukazi, koje je prilikom konzervatorsko-restauratorskih istraživanja i zahvata uočila, sugeriraju da su Ponzonijeve slike izvorno imale drvene podokvire, kao što je uobičajeno za slikarska djela na platnu. ${ }^{6}$ Kako u plitkim svodnim kasetama, kamo su poslije premještene, nije bilo mjesta za drvene podokvire, slike su s njih morale biti skinute te zalijepljene koštanim ljepilom izravno na drvenu podlogu i pritom ponešto skraćene te preinačene iz pravokutne u oktogonalnu formu. ${ }^{7}$ Izuzev središnjih dviju slika sve su zakrenute za 45 stupnjeva. Četiri slike na lijevoj strani zakrenute su u smjeru kazaljke na satu, dok su četiri slike na desnoj strani svoda zakrenute ulijevo, odnosno u smjeru obrnutom od kazaljke na satu (sl. 2). Taj će nam podatak biti važan prilikom rekonstrukcije izvorne 


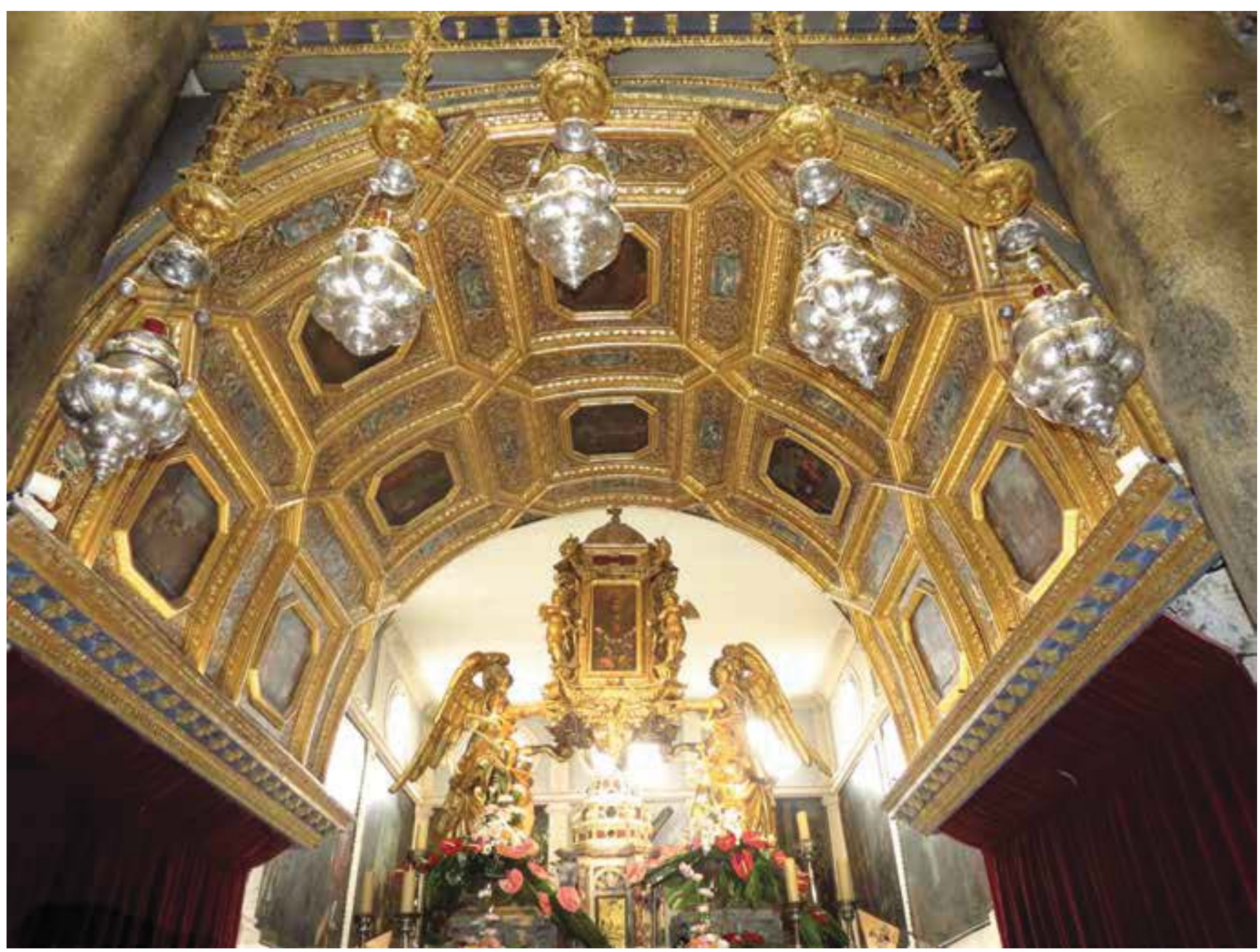

1. Glavni oltar splitske katedrale Uznesenja Marijina

Main altar in the Split Cathedral of the Assumption of the Virgin

zamisli cjeline i njegove ikonografsko-ikonološke raščlambe. Uzevši u obzir pretpostavljene izvorne mjere slika, činjenicu da su imale drvene podokvire te njihovu ikonografsku okosnicu, Žana Matulić Bilač zaključila je da su slike jamačno bile posložene u dva vodoravna niza u obliku dvaju manjih poliptiha te je predložila njihov smještaj na dvama bočnim, nasuprotnim zidovima niše glavnog svetišta katedrale. Svoje je hipoteze potkrijepila računalnim ilustracijama rekonstrukcije svetišta. ${ }^{8}$ Vjerujem da je kolegica Matulić Bilač došla najbliže mogućem rješenju izvornog oblika slikarske cjeline, premda smatram da je ona bila integralna, odnosno jedinstveni poliptih predodređen za drugu poziciju i funkciju unutar svetišta. Stoga ću ovdje ponuditi svoju hipotezu, koja se ponajprije zasniva na novoj interpretaciji rijetkih i već objavljenih arhivskih podataka u vezi s glavnim oltarom splitske stolnice te na sličnim poredbenim primjerima. $\mathrm{Na}$ temelju takvih promišljanja, koja će biti detaljnije razložena u nastavku teksta, vjerujem da je Ponzonijev poliptih, s dvama vodoravnim registrima simetrično raspoređenih slika, bio u funkciji pokrova velike gotičke srebrne pale Ivana Gerardova iz Pesara, koja se nalazila na glavnom oltaru splitske katedrale, odnosno u vrijeme Ponzonijeva i dijelom Bon- dumierova nadbiskupovanja pored oltara sv. Dujma, kako misli Arsen Duplančić. ${ }^{9}$

\section{Pale od plemenitih kovina u jadranskom bazenu i njihove "oslikane vratnice«}

Splitska je katedrala imala dvije pale od plemenitih kovina, od kojih se srebrna i pozlaćena pala Ivana Gerardova iz Pesara (Johannes Gerardini de Pensauro) ${ }^{10}$ iz 1369. godine nalazila na glavnom oltaru splitske katedrale. ${ }^{11}$ Imala je velik broj svetačkih likova i bila je sastavljena od dva dijela, vjerojatno dva vodoravna registra. ${ }^{12}$ Ona je još početkom 17. stoljeća, po svoj prilici, imala i »naslikane vratnice koje su se možda sklapale«, kako je to zaključio Cvito Fisković na temelju izvješća Priulijeve vizitacije koja je izvršena 1603. godine za vrijeme nadbiskupovanja Markantuna de Dominisa. ${ }^{13}$ Priulijev opis navodi nas na razmišljanje $\mathrm{o} »$ naslikanim vratnicama « u smjeru njihove funkcije kao pokrova srebrne pale, odnosno onoga što poznajemo pod nazivom pala feriale. Takvi su oslikani pokrovi svakodnevno bili izloženi i vidljivi na oltaru, a skidali bi se ili otvarali jedino za vrijeme 


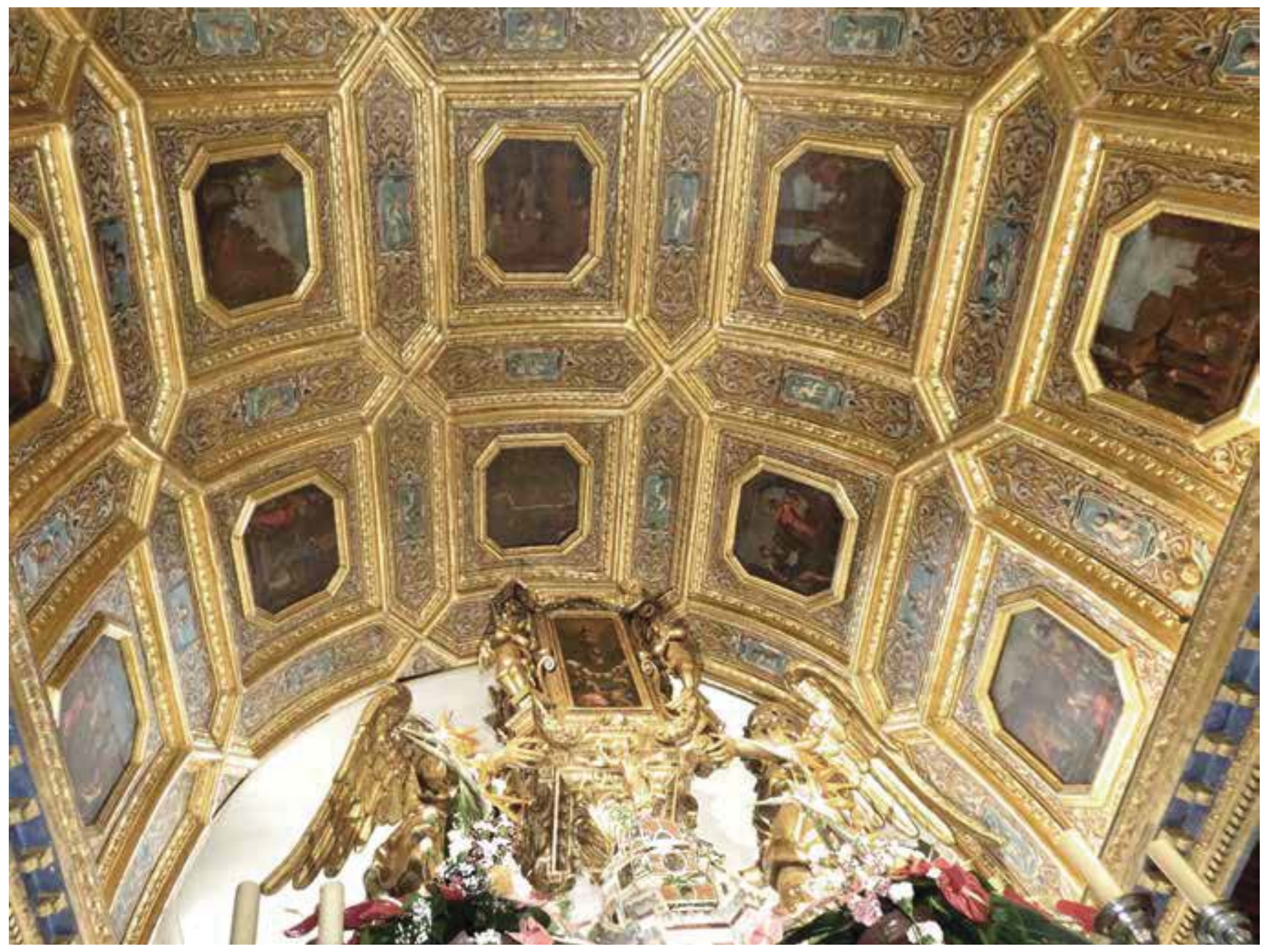

2. Glavni oltar splitske katedrale Uzesenja Marijina, pogled na svod sa slikama

Main altar in the Split Cathedral of the Assumption of the Virgin Mary, view of the vault with the paintings

velikih svečanosti i posebnih dana u vjerskom kalendaru kako bi se tada omogućio pogled na srebrnu pozlaćenu palu, koja je inače bila zaklonjena pogledu vjernika. Najpoznatija pala feriale svakako je ona koju je između 1343. i 1345. godine naslikao venecijanski slikar Paolo Veneziano u suradnji sa svojim sinovima i to kao pokrov za palu od plemenitih metala u bazilici svetoga Marka u Veneciji poznatiju kao Pala d'oro. Ona se rastvarala kompleksnim, gotovo scenografskim načinom, presavijajući se dva puta po uzdužnoj osi ${ }^{14}$ a za pokretanje tog složenog mehanizma korištena je ručica smještena iza oltara. ${ }^{15} \mathrm{Grad}$ na lagunama je, čini se, imao desetak oltarnih pala od plemenitih kovina koje su nastale po uzoru na Palu d'oro. Do danas su se u gradu sačuvale svega tri, a sve su, bez iznimke, imale pokrovne pale. ${ }^{16}$ Pored one iz bazilike sv. Marka sačuvala se srebrna pozlaćena pala glavnog oltara nekadašnje venecijanske katedrale San Pietro di Castello (od 1807. godine nalazi se u Tesoro di San Marco) ${ }^{17}$ te pala u crkvi San Salvador za koju je prvotnu palu feriale izradio Giovanni Bellini, a koju je zbog oštećenja zamijenila Tizianova pala s temom Preobraženja Kristova (nastala oko 1560.-1563. godine), još in situ s pomičnim/kliznim mehanizmom za otvaranje u funkciji. ${ }^{18}$ Tradiciju opremanja oltara palama od plemenitih kovina njegovale su i crkve na istočnoj obali Jadrana. ${ }^{19}$ Dubrovnik je imao više srebrnih pala, ${ }^{20}$ a zadaća izvedbe njihova pokrova bila je povjerena najboljim tadašnjim slikarima, među kojima Lovru Dobričeviću, njegovim sinovima Marinu i Vici te Nikoli Božidareviću. ${ }^{21}$ Nažalost, one se nisu sačuvale. ${ }^{22}$ Zadar je vjerojatno imao jednu srebrnu palu, ${ }^{23}$ a imaju ih još katedrale u Kotoru, ${ }^{24}$ $\mathrm{Krku}^{25}$ i Poreču ${ }^{26}$ premda ne u izvornoj funkciji ili obliku. Srebrnu pozlaćenu palu prekrivenu oslikanim pokrovom posjedovala je i trogirska katedrala, s kojom splitska dijeli brojne analogije u području crkvene opreme i inventara. Ovako ju opisuje trogirski povjesničar Ivan Lucić: »... la Pala antica di legno fata in due pezzi l' uno sopra l' altro, che si apriva, e serrava, e nelli giorni feriali si vedevano due ordini di figure del Salvatore, della Madonna, Apostoli, \& altri Santi dipinti sopra tavole, e nelli festivi li stessi due ordini di figure fatte d' argento dorate ad imitatione di quelle di San Marco di Venetia... $\ll^{27}$ Palu feriale koja je zatvarala srebrnu palu glavnoga oltara u Trogiru izveo je slikar Benedetto Coda u 16. stoljeću, a za nas je osobito važna jer još postoji i njezina je nekadašnja funkcija nedvojbena ${ }^{28}$ (sl. 3). Ona se sastoji od dvije daske položene po dužoj osi, a dispozicija naslikanih 


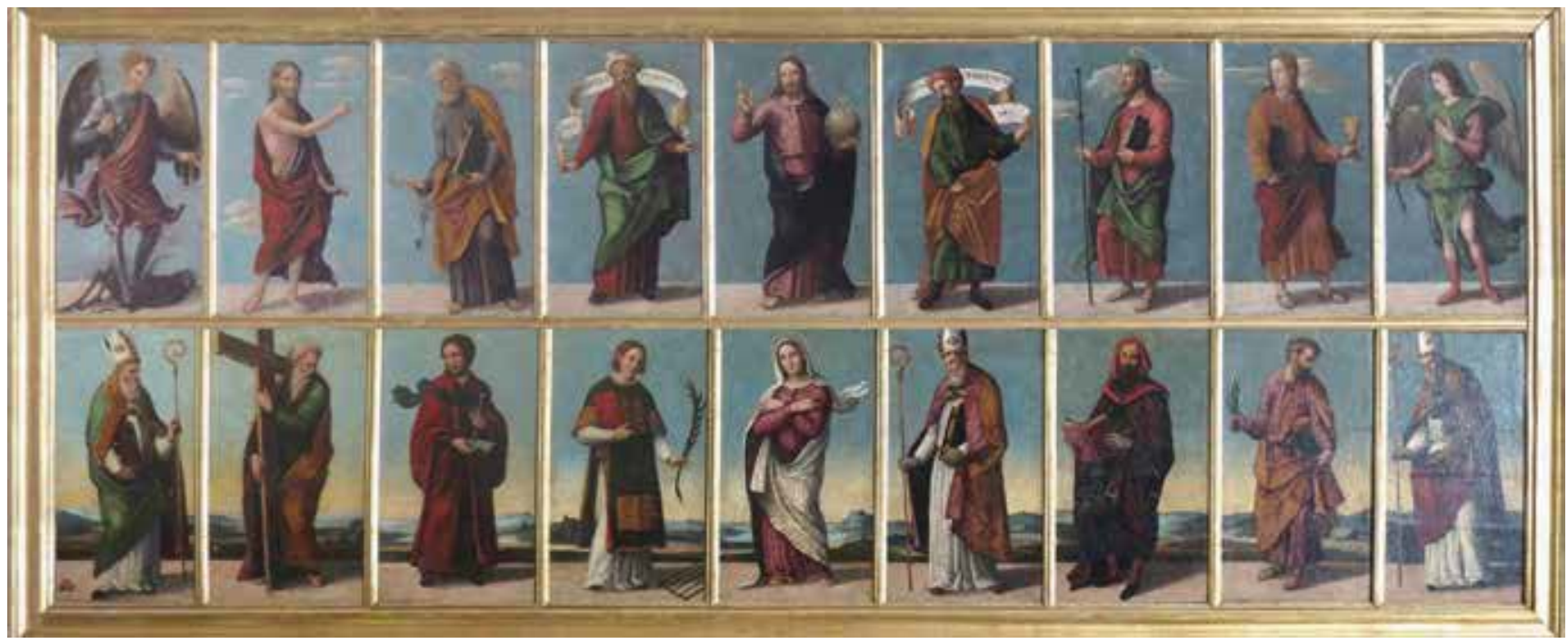

3. Benedetto Coda, Računalna rekonstrukcija poliptiha, katedrala sv. Lovre, Trogir

Benedetto Coda, computer reconstruction of the polyptych, Cathedral of St Laurence, Trogir

figura, po četiri sa svake strane središnjeg prikaza svakog komada, sugerira da je konstrukcija zaista bila slična pali feriale mletačke, duždeve bazilike s kojom se uspoređuje. Stoga se jamačno morala i sklapati na sličan način - prelamajući se po uzdužnoj osi. U vrijeme Priulijeve vizitacije splitske katedrale 1603. godine, dotadašnji je oslikani, drveni pokrov srebrne pale već bio dotrajao, pa je vizitator dao nalog da se naslika novi. ${ }^{29}$

Odredaba koje nalažu obnovu zastarjelih ili oštećenih pokrovnih pala bilo je i drugdje. Tako je 1547. godine slikar Kristofor Antunović dobio zadatak obnoviti okvir s oslikanim vratnicama pale glavnog oltara crkve sv. Vlaha u Dubrovniku, ${ }^{30}$ a Danijel Ciković vjeruje da su tri slike koje prikazuju Bogorodicu s Djetetom i porečke patrone, sv. Maura i sv. Eleuterija, možda segmenti druge pale feriale za srebrnu palu porečke katedrale. ${ }^{31}$ Riječ je o slikama iz 1696. godine koje se pripisuju venecijanskom slikaru Giovanniju Fedrigazziju. ${ }^{32}$ Što se tiče kotorske pale, nalazimo opis iz 1765. godine u vizitacijama biskupa Stefana dell'Oglia, koji kaže: »...za običnih se dana pala zatvara drvenim vratima, urešenim iznutra i izvana slikama svetaca, naslikanim na platnu, koje služe za palu. Pošto su dosadašnje zbog starosti poderane i nepristojne, naredilo je njegovo gospodstvo da se čim prije načine nova vrata, zgodna i urešena slikama, ili zgodan zastor, na kojemu ima biti slika sv. Tripuna, napravljen tako da se oltar može otvoriti i zatvoriti i da se može očistiti od prašine. «33 Taj je podatak iznimno važan jer svjedoči da su pokrovne pale mogle biti izrađene podjednako od drva kao i urešene slikarskim djelima na platnu te da se o pokrovima srebrnih pala vodilo računa barem do druge polovice 18. stoljeća.

Gerardova se srebrna pala u arhivskim dokumentima naziva magna ili grande, a još je apostolski vizitator Agostino Valier u dekretu svojih vizitacija naveo da za nju neće biti mjesta na oltaru nakon probijanja istočnog zida svetišta iza oltara $i$ gradnje novoga kora, pa je treba iskoristiti na drugi način. ${ }^{34}$
Žana Matulić Bilač iznijela je pretpostavku da je ona mogla biti široka oko 300 centimetara, ${ }^{35}$ pa bi Valierove opaske po svoj prilici bile na mjestu, s obzirom na širinu svetišta ${ }^{36}$ te $s$ obzirom na to da Garzadori i Bondumier palu spominju sa strane oltara sv. Dujma. ${ }^{37}$

Podsjetimo da je venecijanska Pala feriale iz sv. Marka velika $325 \times 120 \mathrm{~cm}$. Dimenzije krčke srebrne pale iznose $280 \times 127$ $\mathrm{cm},{ }^{38}$ porečke $280 \times 125 \mathrm{~cm} .{ }^{39}$ Prema izračunima Ivane Prijatelj Pavičić, pala glavnog oltara dubrovačke katedrale iznosila je približno $260 \times 100 \mathrm{~cm}^{40}$ Zbroj dimenzija Ponzonijevih deset svodnih slika, posloženih u poliptih s dvama vodoravnim registrima iznosi otprilike $300 \times 120 \mathrm{~cm}$. Uzmemo li u obzir da je srebrna pala morala biti istih dimenzija ili nešto manja od toga, ona se po veličini uklapa u skupinu srodnih jadranskih primjera. ${ }^{41}$ Možemo li to smatrati potvrdom naše hipoteze o funkciji Ponzonijevih slika? Duplančić misli da je srebrna Gerardova pala uklonjena s oltara oko 1660. godine i spremljena u riznicu, s obzirom na to da je evidentirana $u$ popisu inventara riznice 1665 . godine. ${ }^{42}$ Vjerujem da pala nije morala ni tada biti sklonjena u riznicu premda se nalazi u popisu njezina inventara. Naime, pala je 1400. godine također bila popisana kao dio inventara riznice premda se nalazila na glavnom oltaru. ${ }^{43}$ Štoviše, spomenuti inventar riznice iz 1665. godine navodi: »La Pala di Argiento grande serata del altar. $\aleph^{44}$ Iz toga proizlazi da je pala tada još bila zatvorena, odnosno da je vjerojatno imala svoj slikani pokrov. Uzmemo li u obzir njezine zavidne dimenzije, ona u integralnoj formi (zatvorena palom feriale) nije mogla ni biti pohranjena $u$ riznici koju je tada činio jedan veći drveni ormar. ${ }^{45}$ Godine 1682. »temeljiti i iscrpni Cosmi «, kako ga naziva Duplančić, ${ }^{46}$ vidio je među razlomljenom srebrninom u riznici palu nekadašnjeg oltara, sastavljenu od dva dijela, te je dao nalog za njezinu „bolju upotrebu“. ${ }^{47}$ Rastakanje srebrne pale nije se izvelo tada, no ona se u Cosmijevoj vizitaciji i svim idućim popisima inventara spominje bez pokrova, što nas ponovno navodi na pomisao da je, tada ili nešto prije, pokrovna pala 

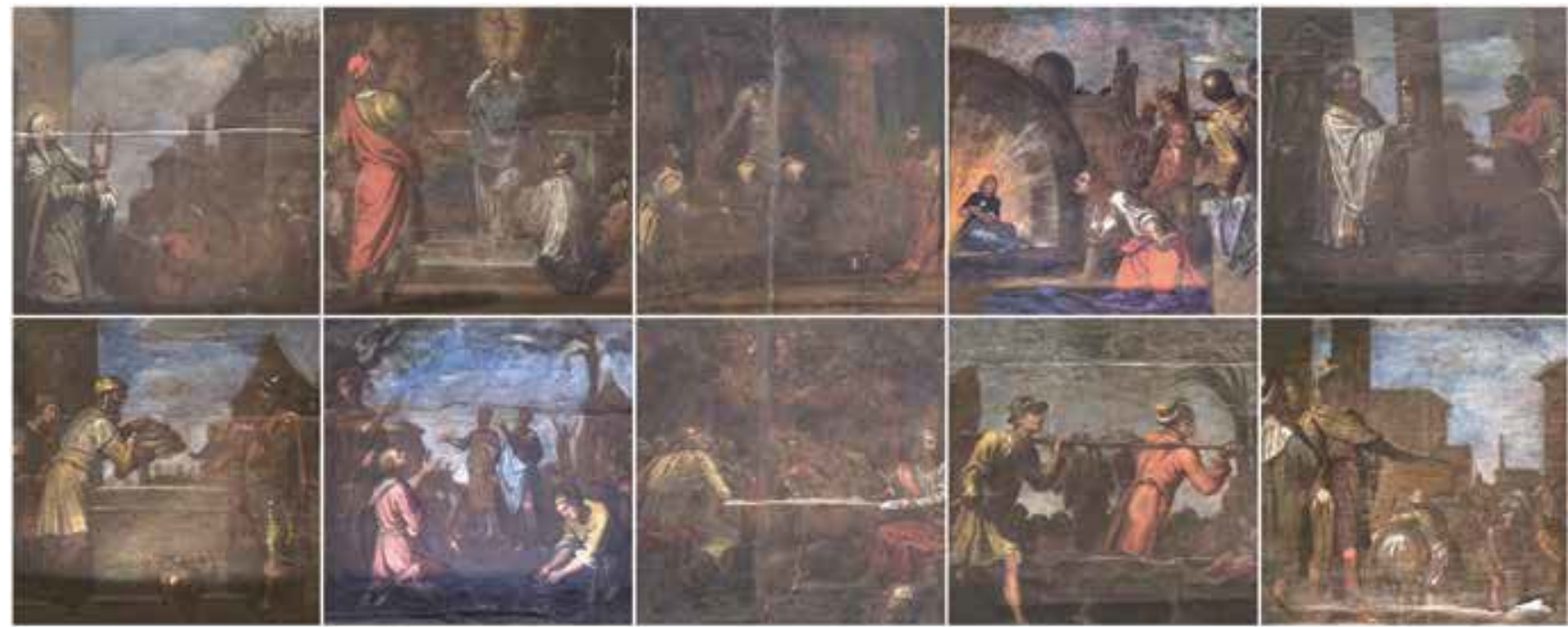

4. Matteo Ponzoni - Pončun, Računalna rekonstrukcija izvornog izgleda poliptiha

Matteo Ponzoni - Pončun, Computer reconstruction of the original appearance of the polyptych

skinuta kako bi bila reutilizirana za novu, svodnu kompoziciju, izvedenu između 1682. i 1689. godine.

\section{Stilske značajke Ponzonijevih slika i ikonografija slikarskog ciklusa u prilog hipotezi o izvornoj ubikaciji i funkciji}

Da Ponzonijeve slike nisu izvorno mišljene kao sadržaji za svodnu kompoziciju, kako se to gdjekad pomišljalo, ${ }^{48}$ govori i perspektiva naslikanih djela. U venecijanskom slikarstvu Cinquecenta i idućih stoljeća uobičajeno je bilo da se stropne slike prikazuju u perspektivnom skraćenju u odnosu na očište promatrača, kao što je već odavna istaknuo Vladimir Marković analizirajući dalmatinske primjere zidnoga slikarstva koji su izravan sljednik venecijanskih umjetničkih težnja: "Odmah je potrebno podsjetiti da su ti drveni oslikani stropovi kao dekorativni tip vezani uz renesansno i manirističko razdoblje venecijanske kulture. Pa i organizacija njihovih slika utemeljena je na venecijanskim rješenjima, tako da im je prostornost prikazana na tipično venecijanski način u kosom pogledu odozdo i u svakoj je slici usmjerena u zasebnom smjeru. « ${ }^{49}$ Premda kod Ponzonija i srodnih primjera nije riječ o stropnim već svodnim kompozicijama, Marković ih smatra »umanjenim mjerilom " oslikanih kasetiranih polja. ${ }^{50}$ Unutar splitske katedrale takva rješenja u kosom pogledu pronalazimo na svodu s ciklusom posvećenim Bogorodici, iznad Morlaiterova oltara sv. Dujma ${ }^{51}$ koji se pod upitnikom pripisuje slikaru Pieteru de Costeru, ${ }^{52}$ a zatim i na svodnim slikama Venecijanca Bartola Bossija koje su se nekada nalazile u ciborijima, iznad oltara sv. Staša i sv. Dujma..$^{53}$ Takve iluzionističke prostornosti na Ponzonijevu splitskom ciklusu nema. Stoga vjerujem da su djela otprva mišljena za pogled u razini promatračevih očiju. Nadalje, jedinstvena ikonografija ciklusa koja brani i učvršćuje nauk o transsupstancijaciji redovito je bila naručivana za kapele sv. sakramenta ili su ih naručivale bratovštine svetoga sakramenta. S obzirom na to da se bratovština sv. sakramenta brinula o inventaru glavnog oltara splitske prvostolnice, i ta činjenica govori u prilog namjeni slika za glavni oltar. ${ }^{54}$ Hipotezi o izvornom smještaju Ponzonijevih slika posvetila sam ovdje nešto više pozornosti, jer je iz navedenoga razvidno da je njihova ikonografska poruka, koja je zahvaljujući dostupnosti pogledu vjernika, mogla biti jasnije i očitije emanirana u odnosu na današnji smještaj slika pod svodom oltara.

\section{Ikonografsko-ikonološka interpretacija Ponzonijeva slikarskog ciklusa}

Prilikom ikonografsko-ikonološke analize ciklusa valja nam imati na umu da je slijed slikarskih djela zbog prenamjene funkcije, novog smještaja i drukčijeg pogleda na cjelinu vjerojatno ponešto izmijenjen u odnosu na izvorni, premda je, kako ćemo nadalje objasniti, podjela na parove sačuvana. ${ }^{55}$ Naime, s obzirom na to da su slike zakrenute za 45 stupnjeva, valja ih čitati od ishodišta prema tjemenu svoda, pri čemu starozavjetna tema odgovara jednom od narativnih egzempla,$^{56}$ dok su dvije središnje slike zadržale centralnu poziciju. Kada bismo ih u parovima izrezali sa svoda i vratili u oblik poliptiha, izvornu bi zamisao činio niz starozavjetnih prizora, u čijoj bi se središnjoj osi nalazila slika s prikazom Posljednje večere. Pandan toj slici, u središnjoj osi gornjega niza, činio bi prizor Krista čiju krv skupljaju anđeli, a koju s obiju strana flankiraju slike kojih bi zajedničku ikonografsku okosnicu bilo ispravno nazvati euharistijska egzempla ${ }^{57}$ (sl. 4). Na taj bismo način dobili logičan poredak u kojem izabrane teme iz Staroga zavjeta prefiguriraju nauk o transsupstancijaciji te posljedično niz euharistijskih egzempla - primjere ilustrativnih, didaktičkih priča kojima je zadaća podučavanje i učvršćivanje misterija euharistije medijacijom propovijedi i vizualno uprizorenih čuda. Ona su mahom derivirana iz srednjovjekovnih literarnih i vizualnih naracija, ${ }^{58}$ 


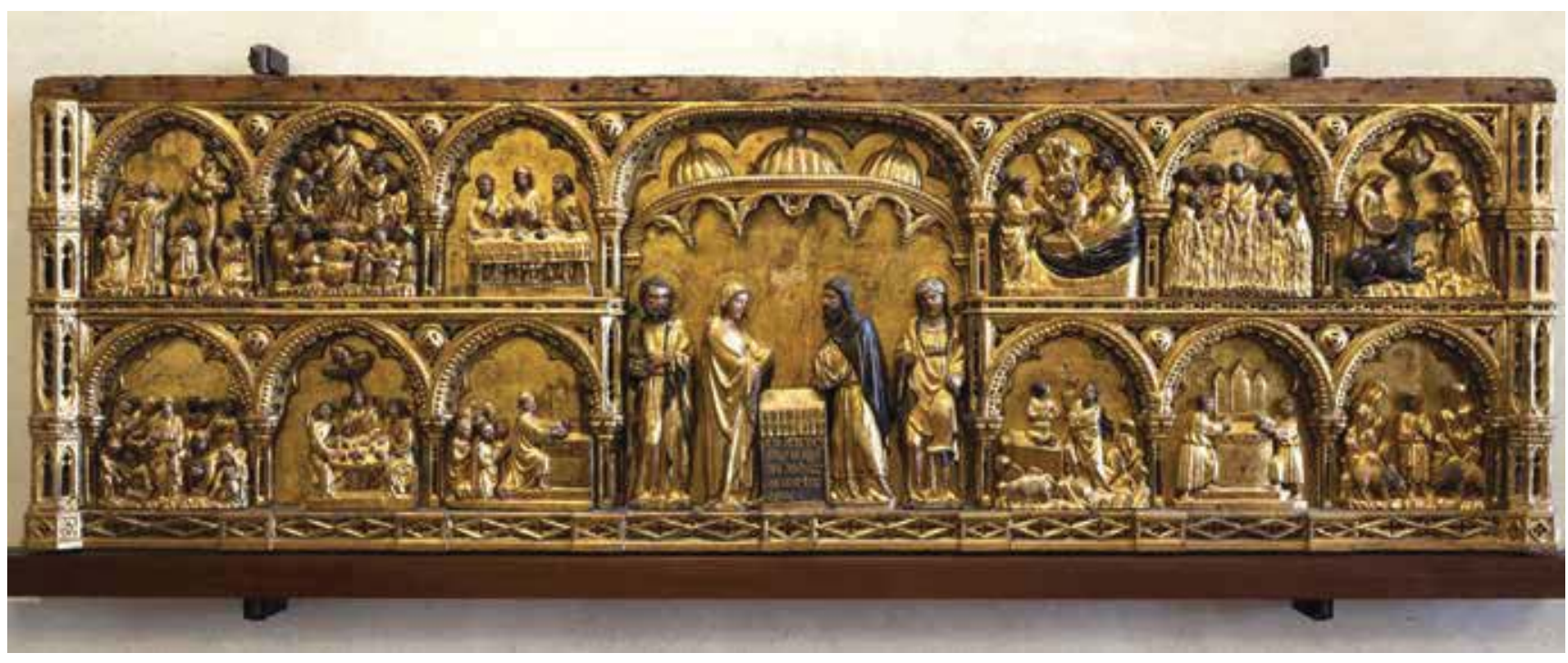

5. Caterino d'Andrea i Bartolomeo di Paolo, oko 1400, poliptih iz nekadašnje crkve Corpus Christi u Veneciji, danas u muzeju Museo Correr u Veneciji

Caterino d'Andrea and Bartolomeo di Paolo, ca. 1400, polyptych from the former church of Corpus Christi in Venice, today at the Museo Correr in Venice

a zajedničko im je da u čudesnim događajima posreduje posvećena hostija. Kako je to istaknula Catherine Harding, razmatrajući primjere ilustrativnih egzempla u kapeli korporala katedrale u Orvietu, neizostavno su u priču upleteni predstavnici marginaliziranih skupina srednjovjekovnog društva: Židovi, žene, heretici ili klerici kojima je potrebna dodatna poduka. ${ }^{59}$ Stoga je takav cjelokupan poredak svojevrsni traktat o euharistiji izveden u slikarskom mediju, pri čemu se izravno naslanja na srednjovjekovne koncepte Biblije pauperum, Speculum Humanae Salvationis ili još bliže na alegorični koncept Biblije Moralisée, koji koriste vizualne i tekstualne korelacije između Staroga i Novoga zavjeta, odnosno ljudi i događaja u biblijskom svijetu te ljudi i događaja u srednjovjekovnom svijetu. Pritom se kronološki slijed događaja najčešće ne poštuje. Jedno venecijansko rješenje, nastalo oko 1400. godine, zoran je primjer takve ikonografske sheme. Riječ je o antependiju oltara iz dominikanske crkve Corpus Christi u Veneciji koji su izradili Caterino d'Andrea i Bartolomeo di Paolo (danas u Museo Correr u Veneciji, sl. 5). Oko središnjeg prizora Prikazanja Kristova u hramu niže se slijeva i zdesna po šest prizora simetrično raspodijeljenih $\mathrm{u}$ dva vodoravna registra. Pritom starozavjetni niz donjega reda odgovara prizorima iz gornjega registra, koji tvore scene iz Novoga zavjeta te dvije srednjovjekovne legende. ${ }^{60}$

Prvi starozavjetni prizor u Ponzonijevu ciklusu vjerojatno je bila scena koja prikazuje Melkizedekovu žrtvu. Melkizedek je prikazan na lijevoj strani slike, odjeven u žutu odjeću, dok polaže pladanj s kruhom na žrtvenik. Iza njega je pomoćnik koji nosi krčag, napunjen vinom, dok se drugi krčag nalazi podno žrtvenika. Desnu stranu slike zauzima Abraham, koji je odjeven poput vojnika u metalnom oklopu s prebačenim crvenim plaštem i kacigom na glavi. Melkizedekov prinos kruha i vina jedna je od najčešće korištenih prefiguracija posljednje večere (koja se nalazi u središnjoj okosnici niza) i euharistije. ${ }^{61}$ Melkizedeka je još sv. Ambrozije nazvao auctor sacramenti pa njegova vizualna reprezentacija ulazi u crkvene knjige, primjerice na početnom inicijalu riječi Te igitur misnoga kanona, tako učvršćujući njegovu vezu »svećenika Boga Svevišnjega" s kršćanskim svećenstvom. ${ }^{62}$ Takva se interpretacija temelji na Psalmu 110 (109):4 - Ti si svećenik dovijeka po redu Melkizedekovu! «, ${ }^{63}$ a isti tekst korist i sv. Pavao u Poslanici Hebrejima 7:17. ${ }^{64}$ Valja napomenuti da taj psalam ulazi u molitve i zazive koji se recitiraju i pjevaju za liturgiju svetkovine Tijelova. Obrazac mise, časoslova Tijelova i pet himni poznatih pod zajedničkim nazivom Officium de Festo Corporis Christi sastavio je i komponirao još sveti Toma Akvinski. No o značaju kruha i vina koje Melkizedek nudi Abrahamu razvile su se žustre rasprave tijekom 16. stoljeća. Katolički stav u tom je smislu nedvojben: to je bila Melkizedekova žrtva, dok su protestanti smatrali da je to samo okrepa koju je po tradicionalnom običaju ponudio kralj Melkizedek (ne svećenik!) pobjedniku te da nema nikakve veze sa sakramentom..$^{65}$ Sljedeća slika starozavjetnog niza po svoj je prilici bila Pad Mane, jedna od najčešće korištenih tema u kapelama sakramenta. ${ }^{66} \mathrm{U}$ Ivanovu evanđelju citamo: "Oci su vaši jeli manu u pustinji, i pomriješe. Ovo je kruh koji silazi s neba da tko jede od njega, ne umre. Ja sam kruh živi koji siđoh s neba ${ }^{67}$, a drugom dijelu laude Lauda Sion Salvatorem (koja čini jednu od pet himni Tijelova), sveti Toma Akvinski navodi Pad mane kao još jednu od nedvojbenih prefiguracija euharistije (»In figúris præsignátur ... Datur manna pátribus«). Središnju os ove kompozicije čine dvije muške figure, čija je silueta razvidna pred pozadinom plavoga neba. To su po svoj prilici Mojsije i Aron. Iza njih i pred njima je mnoštvo; jedna je osoba podigla ruke visoko prema nebu, druga već kleči i sabire manu. Jedan čovjek na lijevoj strani upire kažiprstom prema središtu slike, dok dvoje drugih, u prvom planu (muškarac i žena), kleče: on raskriljenih ruku i pogleda uprta u nebo, dok je žena zaokupljena oko pohrane nebeske hrane. Prizor oslikava riječi iz 
Biblije prema kojima je Mojsije zapovjedio da se jedan vrč napuni manom i pohrani u kovčeg zavjeta ${ }^{68}$ (In tabernaculo reservandum) ${ }^{6}{ }^{6}$ što se može primijeniti na čuvanje euharistije u tabernakulu. ${ }^{70}$ Poštujući zatečenu dispoziciju treća slika, starozavjetna scena, mogla bi biti Kanaanski grozd. Na njoj su prikazana dvojica uhoda, Jošua i Kaleb, na povratku iz kanaanske zemlje kamo ih je poslao Mojsije po zapovijedi Gospodinovoj..$^{71}$ Pred pozadinom plavog neba dominiraju dvije figure muškaraca u pokretu koji sugerira koračanje. Prednji je lik tamnije puti, odjeven u crvenu tuniku i žutu kapu, dok je muškarac iza njega odjeven u zeleno-žutu tuniku i šešir. Između sebe zajednički drže motku na kojoj vise veliki grozdovi grožđa. Sagledana u kontekstu cjelokupnog ciklusa, tema kanaanskog grozda ima dvojako značenje: grožđe iz kojega se tiješti vino prefiguracija je euharistijskog vina koje predstavlja krv Kristovu, dok je drugo značenje ono koje navodi da je prvi nosač, tj. prednji, onaj koji ne vidi grozd na motki iza svojih leđa, simbol sinagoge ili židovskog naroda koji nije uvidio istinu, to jest Krista, a drugi nosač, koji vidi što pred sobom nosi na motki, simbol je Crkve ili pokrštenih pogana koji su Kristovu istinu prihvatili. ${ }^{72}$ Posljednji je prizor u nizu Josip i braća. Lijevu trećinu slike zauzimaju tri lika u stojećem stavu: Josip u smeđe-ljubičastoj tunici i plaštu oker boje okružen je sa svoja dva tumača u odjeći po orijentalnoj modi. Njegova ispružena lijeva ruka, u kojoj je štap, sugerira zapovjedni govor - naredbu. ${ }^{73} \mathrm{U}$ drugom planu slike, koji zauzima desne dvije trećine, nekoliko muških figura užurbano radi na utovaru žita, koje u vrećama tovare na magarce. Neki od patrističkih komentara savršeno su uklopili priču o Josipu kako bi odgovarala euharistijskim himnama ${ }^{74} \mathrm{i}$ čitanjima na svetkovinu Tijelova. Naime, Josip se smatra predslikom sama Krista, a njegova podjela žita predslikom Kristova umnažanja kruha; što je pak prefiguracija same euharistije. ${ }^{75}$

Za našu su temu ovdje poglavito zanimljive slike za koje vjerujem da su se nalazile u gornjem nizu poliptiha, simetrično raspoređene oko središnje slike Anđeli skupljaju Kristovu krv (koju možemo smatrati sažetkom legende o misi sv. Grgura) $)^{76}$, a u vertikalnoj korelaciji s donjim prizorima. Tako je prva slika gornjega niza mogla biti slika koja u razmjerno jednostavnoj kompoziciji prikazuje sv. Klaru u redovničkoj odori kako kleči pred posvećenom hostijom u piksidi, koju drži u rukama. Iza nje su dvije koludrice ruku sklopljenih u molitvi, a pred njom zidine grada s kojega naviru naoružani neprijatelji. Poglavito se među njima ističe jedan tamnoputi lik, s bijelim turbanom na glavi, koji gestikulacijom tijela, širom raširenim rukama, odražava zaprepaštenje. Ta se reprezentacija odnosi na enigmatičnu epizodu iz 1240. godine kada su saracenski plaćenici cara Fridrika II. napali San Damiano, mali, nezaštićeni samostan sestara franjevki u Assisiju. Dok su se ostale redovnice prepale tako da im se "srce topilo od straha«, sveta se Klara, premda bolesna, hrabro suprotstavila neprijatelju. Pomolila se pred raskošno ukrašenom piksidom u kojoj je bila posvećena hostija i zatražila pomoć Božju, a zatim ju je izložila pred neprijatelja. Kada su napadači ugledali sveti sadržaj, panično su se dali u bijeg. Najbolje znana verzija priče nalazi se u knjizi Vita Prima Beati Francesci koju je napisao fra Toma Čelanski oko 1255.-60. godine, dok se najraniji znani likovni prikaz nalazi na vratnicama nekadašnjeg relikvijara koji je oslikao Guido iz Siene 1260. godine (danas u muzeju Pinacoteca Nazionale, Siena). Chiara Frugoni na toj je slici uočila dvije skupine plaćenika: jednu vojnika koji padaju sa zida i drugu što čeka ispod zida, a mogla bi se povezati sa Židovima s obzirom na to da su odjeveni u talit. Na taj bi način scena imala i protužidovske konotacije. ${ }^{77} \mathrm{U}$ srednjem vijeku ta ikonografija nije imala veću recepciju, već se sporadično oživljava tek koncem 15 . stojeća, a postaje popularna tek od kasnog 16. stoljeća. Ponovnu pojavu u ranonovovjekovnom slikarstvu tema duguje propovijedima u kojima se naglašavala istaknuta uloga sv. Klare kao zaštitnice protiv Turaka. ${ }^{78}$ Naime, počevši od 16. stoljeća srednjovjekovna percepcija Saracena kao nevjernika, heretika i neprijatelja katoličke vjere poistovjećuje se s Osmanlijama, novom paradigmom neciviliziranoga, barbarskog naroda, a sv. Klara postaje kršćanska heroina koja brani kršćanstvo glavnim simbolom posttridentinske katoličke teologije, odnosno posvećenom hostijom. Iduća slika bila bi ona koju je Kruno Prijatelj nazvao Vizija Djeteta Isusa u hostiji. Ona prikazuje svećenika u plavičastoj kazuli i bijeloj albi koji je okrenut prema oltaru i kazuje misu. U rukama drži izdignutu posvećenu hostiju nad kojom se ukazuje vizija Djeteta Isusa okružena žutom svjetlosti. Pred svećenikom kleči ministrant, a s obiju strana oltara dvije žene. U prvom je planu muškarac odjeven u žutozelenu haljinu i crveni plašt, koji raširenih ruku stoji na nogama i svjedoči događaju. Riječ je o reprezentaciji jedne od mnogih srednjovjekovnih legendi u kojima nevjernik svjedoči viziji djeteta u posvećenoj hostiji, nakon čega se redovito preobraćuje na kršćanstvo. Najranija znana varijanta datira iz trećeg, odnosno četvrtog stoljeća, a zapisana je u životopisu svetoga Bazilija Velikoga u zbirci Vitae Patrum, ${ }^{79}$ pri čemu je viđenje djeteta u podignutoj hostiji imao Židov koji je tražio ispitivanje kršćanske tvrdnje o Stvarnoj Prisutnosti svojom nazočnošću na misi. Nakon čudesnog događaja obratio se na kršćanstvo s cijelom obitelji. Jedna od varijanti iz 1400. godine kazuje kako je kršćanin zamolio prijatelja Židova da ga pričeka pred crkvom dok završi misa kojoj je želio prisustvovati. Židov je čekajući vani postao nestrpljiv, pa je ušao u crkvu upravo u trenutku podizanja hostije. Umjesto hostije Židov je ugledao lijepo dijete, koje ostali nisu vidjeli. Tako se u njegovim očima činilo da vjernici umjesto hostije u usta stavljaju dijete i proždiru ga. Nakon što je ispričao prijatelju kršćaninu što je vidio, ovaj mu je objasnio da je bila riječ o priviđenju kao posljedici njegova židovskog podrijetla zbog krivnje za smrt Kristovu. Nato je Židov odlučio da se više ne izlaže riziku svjedočenja takvim grozotama te se preobratio na kršćanstvo. ${ }^{80}$ Događaji vizije djeteta u posvećenoj hostiji bili su dobro poznati teolozima s obzirom na to se njima bavio sv. Toma Akvinski u svojoj Summa Theologiae, ${ }^{81}$ propovjednicima koji su ih pronalazili u kolekcijama egzempla, te prvim reformatorima s obzirom na to da su spomenuti događaji i tema bili njihova omiljena meta. ${ }^{82}$ Sljedeća slika u nizu bila bi ona koju je Kruno Prijatelj nazvao Čudo u užarenoj peći. Lijevu polovicu kompozicije zauzima prikaz otvorene, nadsvođene peći u kojoj bukti vatra. U njoj mirno sjedi dječak, ruku prekriženih na prsima sred kojih je naslikana posve- 


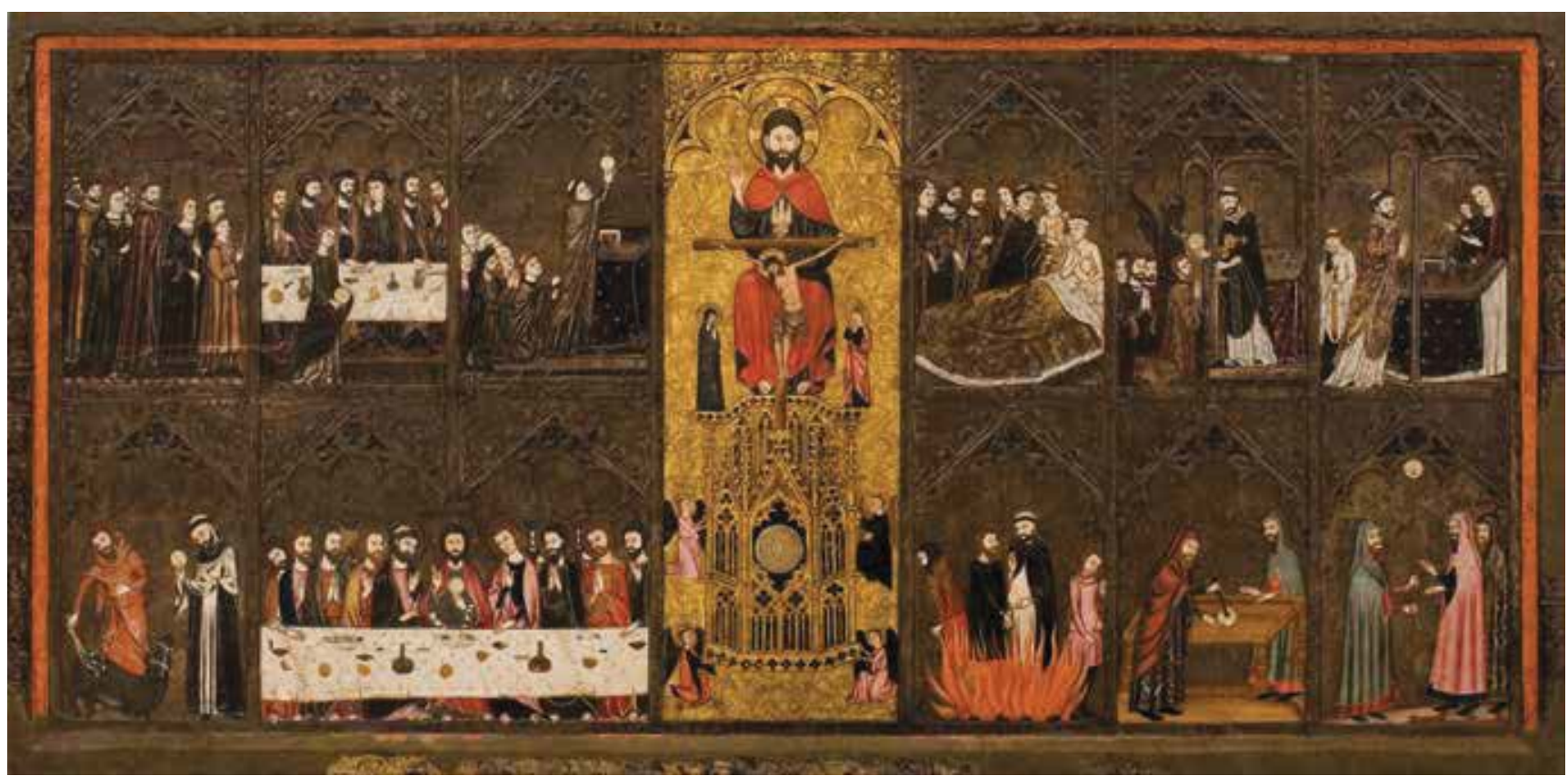

6. Maestro de Vallbona de les Monges (Guillem Seguer ?), 1335.-1345., oltarna pala iz kapele Corpus Christi iz crkve Santa Maria de Vallbona de les Monges, Museu Nacional d’Art de Catalunya

Maestro de Vallbona de les Monges (Guillem Seguer?), 1335-1345, altarpiece from the Corpus Christi chapel in the church of Santa Maria de Vallbona de les Monges, Museu Nacional d'Art de Catalunya

ćena hostija. Desnu polovicu slike zauzima mnoštvo koje žustrim kretnjama izražava čuđenje i zaprepaštenje, komentirajući međusobno događaj. U prvom planu kleči žena, odjevena u bijelu košulju i žarkocrvenu haljinu, koja užasnuto gleda u dijete raširivši obje ruke. Riječ je uprizorenju još jedne popularne srednjovjekovne legende, $s$ više literarnih i likovnih varijanti događaja, nerijetko, u različitim izvedbama, obojenih lokalnim značajkama. Premda je legenda mogla nastati i prije, prva znana i sačuvana je ona koju je zapisao Evagrije Skolastik (oko 536.-600.) u Historia Ecclesiastica ${ }^{83}$ dok je prvu latinsku verziju priče, po uzoru na Evagrijevu, napisao sveti Grgur iz Toursa (Clermont, 30. studenoga 538. - Tours, 17. studenoga 594.) u knjizi De gloria martyrum. ${ }^{84}$ Dok je Evagrije Skolastik radnju smjestio u Carigrad, Grgur iz Toursa navodi neodređeno, negdje na Istoku. ${ }^{85}$ Tamo je, prema njegovim navodima, živio Židov koji se bavio staklarstvom, a sin mu je pohađao školu s kršćanima. Jednoga je dana dječak otpratio prijatelje u lokalnu baziliku sv. Marije, gdje je zajedno s njima primio svetu pričest. Vrativši se kući, ispričao je ocu što je učinio. Otac se zakleo da će se osvetiti te je bacio dječaka u užarenu peć. Dječakova je majka potrčala da ga spasi, no vidjevši vatru kako bukti stala je bespomoćno zapomagati i plakati. Neki kršćani čuli su zapomaganje, pa su ušavši u kuću zatekli neozlijeđena dječaka u peći, koji im je ispričao: $U$ crkvi gdje sam primio kruh sa stola sjedila je žena na prijestolju i u naručju držala dijete. Ona me pokrila svojim plaštem kako me vatra ne bi progutala.«Stoga nema dvojbe da se dječaku ukazala Bogorodica. Nakon tog događaja dječak i njegova majka preobratili su se na kršćanstvo, a njihov su primjer slijedili brojni Židovi, dok je otac bio bačen u peć. ${ }^{86}$ Počevši od 9. stoljeća nadalje priča se modificira pa nastaju brojne inačice, ${ }^{87}$ a u njezinoj recepciji istaknuto mjesto ima kolekcija Les Miracles de Notre-Dame koju je kompilirao oko 1223.-1227. godine Gautier de Coinci (1177.-1236.). On je radnju priče premjestio u francuski grad Bourges, pa je u literaturi engleskoga govornog područja ona do danas ostala najpoznatija pod naslovom The miracle of the Jewish boy of Bourges. Njegova je verzija bila silno popularna i utjecajna, o čemu svjedoče deseci sačuvanih manuskripta ${ }^{88}$ a ujedno je bila prva koja je priču iskazala vizualnom naracijom. ${ }^{89}$ Marijanska je priča postupno izašla iz samostanskih okvira i ušla je kao egzemplum u kolekcije propovijedi. U tom smislu nezaobilazno je spomenuti kasnosrednjovjekovne zbirke poput Alphabetum narrationum. ${ }^{90}$ Dakako, s izumom tiskarstva u novom vijeku priču pronalazimo u knjižnim izdanjima, a poglavito valja izdvojiti naslov Girolama (Silvana) Razzija, Miracoli di Nostra Donna ... cavati da diversi autori cattolici et approvati, prvi put tiskan u Firenci 1576. godine, te nekoliko godina poslije u Veneciji. ${ }^{91}$ Primjera u kojima se legenda o židovskom dječaku pojavljuje u monumentalnom fresko- ili štafelajnom slikarstvu razmjerno je malo. Poznati su mi primjeri fresko-slikarstva u Eton College Chapel u Windsoru i kapeli Blažene Djevice Marije $\mathrm{u}$ katedrali u Winchesteru $\mathrm{u}^{92}$ te freske na sjevernom zidu u kapeli korporala u katedrali u Orvietu ${ }^{93}$ koje je naslikao Ugolino di Prete Ilario između 1357. i 1364. godine, dok je Ponzonijev prikaz na platnu jedini za sada poznat primjer.

Posljednja slika niza činila bi svojevrsni pandan s prvom. Temu poznajemo pod naslovom Čudo poklekle mazge. Na slici dominiraju dvije muške figure; slijeva prepoznajemo sv. Antu Padovanskog (ponajviše zbog aureole i male braće u pratnji), 
odjevena u bijelu svećeničku halju kako u rukama drži piksidu s posvećenom hostijom, dok desnu polovicu slike zauzima poklekla mazga i njezin gospodar, sredovječni muškarac u žutoj tunici zaogrnut crvenim plaštem. Riječ je o legendi koja se po tradiciji vezuje uz sv. Antu Padovanskog, a u likovnom mediju popularizirao ju je polovicom 15. stoljeća Donatello uprizorenjem na oltaru sv. Ante, u svečevoj padovanskoj bazilici. ${ }^{94}$ Vjerojatno je manje poznato da korijeni legende leže u srednjovjekovnim zbirkama egzempla gdje je akter u priči anonimni svećenik. ${ }^{95}$ Jedna od njih kazuje o heretiku koji je svom magarcu davao za hranu neposvećene hostije. Jednom ga je svećenik u raspravi o Tijelu Kristovu upitao da li bi magarac pojeo i posvećenu hostiju. Heretik mu odgovori: »Pojeo bi ih tisuću ukoliko mu se ponude, a ako odbije pojesti, ja ću povjerovati $\mathrm{u}$ to $\mathrm{u}$ što vi vjerujete. "Donese potom svećenik posvećenu hostiju i pruži je magarcu, no ovaj odmah poklekne pred njom. Vidjevši to, heretik se preobrati na kršćanstvo. ${ }^{96}$

Vezivanje legende uz sv. Antu Padovanskog započelo je s njegovim drugim, pisanim životopisom, a zanimljivo je da najranije poznate likovne varijante legende stavljaju u fokus sv. Dominika, ${ }^{97}$ premda legenda nije zabilježena u njegovu životopisu, niti ijedna priča (iz kolekcija egzempla) spominje toga sveca. Ovdje kao primjere izdvajamo nekoliko uprizorenih legendi s dominikanskom ikonografijom: sliku (nekadašnji antependij) neznanog autora iz prve četvrtine 14. stoljeća, koja se danas čuva u Barceloni u Museu Nacional d'Art de Catalunya te oltarnu palu iz kapele Corpus Christi iz crkve Santa Maria de Vallbona de les Monges iz 1335.-1345. godine koja se čuva u istom muzeju. Poglavito je zanimljiv posljednji primjer jer je cjelokupna ikonografija pale posvećena euharistijskim temama, u koju je uklopljena i legenda o svećeniku i magarcu ${ }^{98}$ (sl. 6). Navedimo i jedan kasniji, geografski bliži primjer, onaj iz dominikanske crkve SS. Giovani e Paolo u Veneciji, koji je naslikao Giuseppe Heinz oko 1600. godine. Premda je, kao što vidimo, postojala likovna varijanta legende sa sv. Dominikom, na već spomenutom antependiju iz dominikanske crkve Corpus Cristi u Veneciji, prikazano je čudo poklekle mazge s franjevačkim svecem. Uzimajući u obzir cjelokupnu ikonografiju antependija i njegovu izvornu namjenu, Kaplan misli da taj prizor treba smatrati ilustracijom egzempla, ${ }^{99}$ što vjerujem da možemo primijeniti i na splitski primjer.

\section{Zaključna razmatranja}

U skladu s ikonografsko-ikonološkim razmatranjima Ponzonijevih slika razvidno je da je riječ o nasljeđu srednjovjekovnog koncepta. S tim u vezi može se postaviti pitanje o mogućem preuzimanju starijeg ikonografskog predloška. Doduše, revival srednjovjekovnih tema i koncepcija u posttridentinskoj obnovi crkve nije ni rijetkost ni slučajnost. On je izravan odgovor na krizu unutar Katoličke crkve i pojavu protestantizma. U vrijeme napada protestanata na katolike izvlače se tekstovi temeljnih crkvenih autoriteta te ponovno čitaju, tumače i tiskaju, kao što se obnavljaju i stari ikonografski obrasci. Tridentski koncil potvrđuje i brani sakrament euharistije, odnosno nauk o transsupstan- cijaciji, a poglavito u odnosu na Luthera i reformatore koji su se oduprli vjerovanju da je Krist prisutan u euharistiji na način katoličkog tumačenja. ${ }^{100}$ Tamo gdje su izazovi bili najveći postojala je i povećana potreba za odgovorom na njih. Splitska se metropolija u povijesti u više navrata našla pod utjecajem raznih heretičkih strujanja. Svakako je najpoznatija srednjovjekovna epizoda ona iz vremena nadbiskupa Bernarda, ${ }^{101}$ kada su 1214. godine postavljene vratnice splitske katedrale, po ikonografskom programu pravi antiheretički poster. ${ }^{102}$ Nije naodmet spomenuti kako su vratnice inaugurirane uoči IV. lateranskog koncila, na kojemu je sudjelovao i sam splitski nadbiskup, a kada je službeno ustanovljen nauk o transsupstancijaciji kojemu su se dualni heretici tada, kao i reformatori stoljećima poslije, snažno odupirali. Stoga Ponzonijev ciklus možemo promatrati i kao anagogičku sekvencu u višestoljetnom opremanju i preinakama katedrale te kao odgovor na crkveno-povijesne prilike. Podsjetimo da je u osvit 17. stoljeća Split okružen Osmanlijama, neprijateljima druge vjere i kulture. ${ }^{103} \mathrm{U}$ samu gradu nadbiskup Markantun de Dominis (splitski nadbiskup 1602.-1616.) koketira s protestantizmom, zbog čega je bio priveden pred inkviziciju, ${ }^{104}$ kao i brojni Hrvati koji su pristajali uz protestantski nauk, prelazili na pravoslavlje ili islam ili su imali doticaja s magijom, prizivanjem demona, navođenjem na krivovjerje i nezakonito obavljanje crkvene službe. ${ }^{105} \mathrm{U}$ takvim nemilim vremenima nadbiskupski je tron naslijedio Venecijanac Sforza Ponzoni, koji je stolovao u splitskoj katedrali od 1616. do 1640. godine. On se po svoj prilici odlučio obračunati sa svim vrstama hereze i inovjerstva, a vjerojatno zbog zamaha provedbe programa protureformatorske crkve te želje da pokaže revnost prema rimskoj stolici. Tako je 1619. godine proveo istragu protiv dominikanca Albetija Fertilija, vikara trogirske biskupije, čiju je tužbu potpisao niz trogirskih svećenika. ${ }^{106}$ Svjedočanstva protiv Fertilija eksplicitno navode da je bio zaveden protestantizmom koji je propagirao i širio bivši nadbiskup Markantun de Dominis. ${ }^{107}$ Iste je godine nadbiskup Ponzoni uputio generalnom inkvizitoru u Veneciju i materijale sabrane u istrazi protiv heretika, protestanta Agostina Capogros$\mathrm{sa}^{108}$ o kojemu je svjedočio liječnik Ivan Krstitelj Stuggioli iz Venecije riječima: »Spomenuti Capogrosso ne ide nikada na misu ... Što više sadašnji nadbiskup trpi mnogo od ovakvih ljudi, jer osim spomenutog Capogrossa, ima i drugih, koji žive kao on ... « ${ }^{109}$ Godine 1622. po svim je javnim mjestima grada Splita Ponzoni objavio proglas kojim zabranjuje kršćanima da se liječe kod Židova pod prijetnjom crkvenog prokletstva, ${ }^{110}$ a 1640 . godine zabranio je pravoslavcima da osnuju crkvu u Splitu. ${ }^{111}$ Izbor ikonografije Ponzonijevih slika stoga je potpuno jasan i opravdan crkvenopovijesnim kontekstom te se kao koncept uklapa u program Bratovštine svetoga sakramenta kao i nastojanja nadbiskupa da osnaži vjeru kršćana u borbi protiv inovjernika. Pritom je s pomoću ikonografije slikanih djela proveden proces značenjske zamjene identiteta inovjernika. Naime, ako pogledamo slikane prizore u cjelini, uočit ćemo da su svi inovjernici determinirani na dva načina: žustrim gestama i bojom odjeće. Oni su odjeveni u žarke boje, crvenu i žutu odjeću te pokrivala za glavu. ${ }^{112}$ Distingviranje inovjernika 
(primarno Židova) od ostatka kršćanske populacije bojama odjeće, u kojima prevladavaju žuta i crvena boja, jest praksa ustanovljena u srednjem vijeku, a naslijeđena iz antičkih vremena. ${ }^{113}$ Tada su žarkim odjevnim kombinacijama; najčešće žutim i crvenim, obilježavani pripadnici marginalnih slojeva društva. ${ }^{114} \mathrm{U}$ ovom slučaju inovjernici su pripadnici islama i židovske zajednice, koji postaju paradigmatski neprijatelji Crkve. Dogmatsko pitanje Crkve - nauk o transsupstanci-

\section{Bilješke}

1

KRUNO PRIJATELJ, Barok u Splitu, Split, 1947., 60; ISTI, Matej Ponzoni-Pončun, Split, 1970., 40; ISTI, Neobjelodanjeni ciklus slika Mateja Ponzonija-Pončuna, Split, 1974; ISTI, Barok u Dalmaciji, u: Kruno Prijatelj, Barok u Hrvatskoj, Zagreb, 1982., 822; ISTI, Ciklus slika Mateja Ponzonija-Pončuna u splitskoj katedrali, u: Kruno Prijatelj, Studije o umjetninama u Dalmaciji IV, Zagreb, 1983., 58-66; VLADIMIR MARKOVIĆ, Zidno slikarstvo 17. i 18. stoljeća u Dalmaciji, Zagreb, 1985., 154; RADOSLAV TOMIĆ, Splitska slikarska baština, Zagreb, 2002., 71-75.

2

ARSEN DUPLANČIĆ, Preinake glavnog oltara splitske katedrale u XVII. stoljeću, u: Prilozi povijesti umjetnosti u Dalmaciji, 43 (2016.), 314

3

Nakon restauracije slika izvedene 1973. godine pri Regionalnom zavodu za zaštitu spomenika kulture u Splitu Kruno Prijatelj je napisao: "Nije nam danas poznato gdje su ranije prizori bili smješteni: da li na ranijem možda skromnije ukrašenom svodu, da li su pravili zajedno neki poliptih u Bratovštini Presvetog Sakramenta ili ih je slikar naslikao za svod koji nije mogao biti dovršen za njegova života." KRUNO PRIJATELJ (bilj. 1, 1974.), 19, bilj. 10; vidi također: RADOSLAV TOMIĆ (bilj. 1), 74. Isto pitanje postavlja i Arsen Duplančić u svom recentnom radu posvećenu preinakama glavnog oltara splitske katedrale: ARSEN DUPLANČIĆ (bilj. 2), 315.

4

KRUNO PRIJATELJ (bilj. 1, 1974.).

5

ŽANA MATULIĆ BILAČ, Glavni oltar splitske katedrale konzervacija i restauracija u prostornom kontekstu, 1. Kongres konzervatora-restauratora Hrvatske (KRUH), Split, 7.-8. prosinca 2012.; ISTA, Povijesni razvoj i obnove glavnog oltara splitske katedrale, znanstveno-stručni skup Svetišta dalmatinskih katedrala - rješenja u prošlosti i izazovi obnove, Split - Trogir, 28.-29. rujna 2013.; ISTA, Povijesni razvoj glavnog oltara splitske katedrale, u: Kulturna baština, 40 (2014.), 249-296; ISTA, Glavni oltar splitske katedrale Uznesenja Blažene Djevice Marije - tehnološke i kronološke analize, u: Portal, 7 (2016.), 49-84.

6

ŽANA MATULIĆ BILAČ (bilj. 5, 2016.), 66-67.

7

ŽANA MATULIĆ BILAČ (bilj. 5, 2016.), 67. jaciji - rješava se s pomoću »vanjskog neprijatelja«, koji se oportuno poistovjećuje s Židovima u kolekcijama egzempla i njihovim vizualnim naracijama. Oni u 17. stoljeću postaju metonimija protestantskog identiteta jer i jedni i drugi odbacuju vjerovanje u transsupstancijaciju i svako očitovanje stvarne prisutnosti Kristova tijela u hostiji, ${ }^{115}$ a i zbog toga što protestanti nisu imali posebnih vanjskih obilježja kojima bi ih se u likovnom djelu identificiralo.

8

ŽANA MATULIĆ BILAČ (bilj. 5, 2014.), 289, slika 5 i 6; ISTA (bilj. 5, 2016.), 66-67.

9

Prema posljednjim doprinosima Arsena Duplančića, nadbiskup Leonard Bondumier je između 1652. i 1654. godine naložio da se Gerardova srebrna pala, koja se privremeno nalazila pored oltara sv. Dujma, ponovno vrati na glavni oltar splitske katedrale, da bi oko 1660. godine bila prenesena u riznicu. ARSEN DUPLANČIĆ, (bilj. 2) 305, 309, 318-319.

10

CVITO FISKOVIĆ, Nekoliko dokumenata o našim starim majstorima, u: Vjesnik za arheologiju i historiju dalmatinsku, 52 (1949.), 193; KRUNO PRIJATELJ, Srebrne pale splitske stolne crkve, u: Anali Historijskog instituta JAZU u Dubrovniku, 1 (1952.), 248-250; ISTI, Srebrne pale splitske stolne crkve, u: Kruno Prijatelj, Studije o umjetninama u Dalmaciji I, Zagreb, 1963.,17-23.; ISTI, Srebrne pale splitske stolne crkve, u: Kruno Prijatelj, Kroz povijest umjetnosti u Dalmaciji (XIII-XIX. st.), Split, 1995., 86; NADA KLAIĆ - IVO PETRICIOLI, Zadar u srednjem vijeku, Zadar, 1976., 531; ARSEN DUPLANČIĆ, Splitski spomenici u Kavanjinovu »Bogatstvu i uboštvu«, u: Kulturna baština, 13 (1982.), 25; IVO PETRICIOLI, Arhivske bilješke o zlatarstvu XIV. stoljeća u Splitu, u: Peristil, 35/36 (1992.-1993.), 47-54; IVO PETRICIOLI, Note sugli orefici trecenteschi attivi nell'area adriatica, u: Homo Adriaticus, Ancona, 1998., 267-270; ARSEN DUPLANČIĆ (bilj. 2), 318-320.

11

Druga je pala bila nešto starija i nalazila se na oltaru sv. Dujma, a uklonjena je zbog izgradnje novoga kamenog oltara posvećena splitskom, nebeskom parcu čija je izgradnja povjerena Boninu Jakovljevu iz Milana. KRUNO PRIJATELJ (bilj. 10, 1995.), 85; NIKOLA JAKŠIĆ, Srebrna oltarna pala u Kotoru, u: Ars Adriatica, 3 (2013.), 53.

12

U De Dominisovoj vizitaciji iz 1604. godine pala se opisuje ovako: »Icona dicti altaris maioris in duas divisas partes complicatur et habet multas sanctorum figuras ex lamina argentea relevatas, antiqum sane opus; sed rudis artificii.« Državni arhiv u Splitu (dalje: DAS), Marco Antonio de Dominis: Visitatio generalis facta 1604., prijepis Urbana Krizomalija, 1942., 5. Isti podatak donosi Kruno Prijatelj. Vidi: KRUNO PRIJATELJ (bilj. 10, 1963.), 18; ISTI (bilj. 10, 1995.), 86. Godine 1682. nadbiskup Cosmi palu opisuje ovako: »(...) praecipue iconem olim altaris maioris, quae in duas divisas partes complicatur habens sanctorum figuras ex 
lamina argentea; opus antiquum ac rudis artificis $(..) \ll$, KRUNO PRIJATELJ (bilj. 10, 1995.), 86.

13

»Icon est argento circum quod ordinavit mutari tabulas et ipsas depingi cum sint vetusta." Visitatio apostolica spalatensis 1603 Michaelis Prioli. Archivio Secredo Vaticano. Miscellanea Arm. VII, no. 100, f. 165; CVITO FISKOVIĆ, Neobjavljena romanička Madona u Splitu, u: Prilozi povijesti umjetnosti u Dalmaciji, 12 (1960.), 95, bilj. 34. Zahvaljujem kolegici Žani Matulić Bilač na posudbi kopija apostolskih i biskupskih vizitacija za potrebe pisanja ovoga rada.

14

CRISTINA GUARNIERI, Una pala ribaltabile per l' esposizione delle reliquie: Le storie di Santa Lucia di Jacobello del Fiore a Fermo, u: Arte Veneta, 73 (2016.), 23.

15

Ovako ju opisuje Sansovino: »Ma mirabile \& e fuor di modo inestimabile é la alla del detto altare la cui coperta di fuori fu una parte dell' altar grande di Santa Sofia di Costantinopoli, \& la qual coperta insieme con la Palla, s' apre in due parti da mezzo in su con un molinello a mano posto dietro all' altare. « FRANCESCO SANSOVINO, Venetia, citta nobilissima et singolare, In Venetia, Appresso Iacomo Sansovino, 1581., 36-37.

Antonio Pasini navodi: »(...) parlando della Pala propriamente detta, e che allora si ripiegava sopra di sé, aprendosi di basso in alto col meccanismo di un mulinello (...)«, ANTONIO PASINI, Sul frontale dell'altar maggiore in S. Marco di Venezia: studii, Venezia, 1881., 47. Zanimljivo je da je u 15. stoljeću Pala d'oro opremljena slikanim poliptihom koji se pripisuje slikaru Francescu dei Franceschiju (djelatan u Veneciji od 1443. do 1468.) s funkcijom pokrova njezine stražnje strane (facciata posteriore), a godine 1614. slikar Maffeo da Verona (1574.-1618.) dobio je zadaću napraviti novu facciatu posteriore slijedeći stariji predložak odnosno razdiobu ploha poliptiha i njihov ikonografski sadržaj. LUISA VERTOVA, Maffeo Verona between Paolo Veronese and Tintoretto, u: The Burlington Magazine, 119, 891 (1977., lipanj), 423.

16

Više o venecijanskim srebrnim pozlaćenim palama u: ANTONIO NIERO, Notizie di archivio sulle pale di argento delle lagune venete, u: Studi veneziani, II (1978.), 257-291; ANTONIO NIERO, Censimento delle pale nell'area lagunare, $\mathrm{u}$ : La pala d'oro - il tesoro di San Marco, (ur.) Hans Robert Hahnloser i Renato Polacco, Venezia, 1994.; DANIJEL CIKOVIĆ, Srebrna pozlaćena pala iz krčke katedrale, diplomski rad, Filozofski fakultet, Rijeka, 2011., 28.

17

Ovako ju u vizitaciji opisuje Priuli 1591. godine: »(...) una palla d' argento in due parti divisa, quale si chiude continuamente et $s$ ' apre solo nei giorni delle festivitá principali et in essa appariscono molte figure d' argento indorate di diversi santi (...)«, prijepis prema: ANTONIO NIERO (bilj. 16, 1978.), 261.

18

WILLIAM R. REARICK, La Trasfigurazione di Cristo di Tiziano e il suo altare cinquecentesco nella chiesa San Salvador, u: $L a$ Trasfigurazione di Cristo: Tiziano Vecellio per il sinodo di BellunoFeltre, Cinisello Balsamo, 2005., 15., 20; SILVIA PICHI, Scuole di devozione, Arti e mestieri nella chiesa di San Salvador, u: La chiesa di San Salvador a Venezia - Storia Arte Teologia, (ur.) Gianmario Guidarelli, Padova - Venezia, 2009., 53.

19 JOŠKO BELAMARIĆ, Gotička kultura u Dalmaciji. Razvoj slikarstva između XIII. i XV. stoljeća. u: Stoljeće gotike na Jadranu - slikarstvo u ozračju Paola Veneziana, katalog izložbe, (ur.) Biserka Rauter Plančić, Zagreb, 2004., 18, 20; MILAN PELC, Renesansa, Zagreb, 2007., 415-416.

20

NIKOLA JAKŠIĆ (bilj. 11), 65, bilj. 15; IVANA PRIJATELJ PAVIČIĆ, U potrazi za izgubljenim slikarstvom, O majstoru Lovru iz Kotora i slikarstvu na prostoru od Dubrovnika do Kotora tijekom druge polovice XV. stoljeća, Dubrovnik, 2013., 172; DONAL COOPER, "The silver there is very good": Pilgrim Narratives as Sources for Sacred Art in Dubrovnik and a New Proposal for Lovro Dobričević, u: Towns and Cities of the Croatian Middle Ages. Image of the Town in the Narrative Sources: Reality and / or Fiction?, (ur.) Irena Benyovsky Latin i Zrinka Pešorda Vardić, Zagreb, 2017., 331-358.

21

CVITO FISKOVIĆ, Umjetnine stare dubrovačke katedrale, u: Bulletin Zavoda za likovne umjetnosti JAZU XIII/1-3 (1965.), 63; IVANA PRIJATELJ PAVIČIĆ (bilj. 20), 162-178; DONAL COOPER (bilj. 20), 331-358; ANA MARINKOVIĆ, Kasnosrednjovjekovna crkva sv. Vlaha, u: Zborna crkva sv. Vlaha u Dubrovniku, (ur.) Katarina Horvat-Levaj, Dubrovnik - Zagreb, 2017., 79-80.

22

Koliko je do sada znano, sačuvao se samo srebrni, pozlaćeni reljef sv. Vlaha za koji se vjerovalo da pripada nekadašnjoj kovinskoj pali glavnoga oltara iz crkve sv. Vlaha. Usp: VINICIJE B. LUPIS, O srebrnoj pali i srebrnom reljefu sv. Vlaha, u: Peristil, 51 (2008.), 119-130. U recentnoj literaturi iznesene su dvojbe u skladu s prethodnim tumačenjem izvornog smještaja reljefa sv. Vlaha. Usp: DANIEL PREMERL, Pozlaćeni srebrni kip sv. Vlaha iz 15. stoljeća, u: Zborna crkva sv. Vlaha u Dubrovniku, (ur.) Katarina Horvat-Levaj, Dubrovnik - Zagreb, 2017., 179-183.

23

NIKOLA JAKŠIĆ - RADOSLAV TOMIĆ, Umjetnička baština Zadarske nadbiskupije. Zlatarstvo, Zadar, 2004., 16-17. Citirano prema: VINICIJE B. LUPIS (bilj. 22), 123.

24

MILOŠ MILOŠEVIĆ, Tragovi prve srebrne pale kotorske katedrale iz XIV stoljeća, u: Prilozi povijesti umjetnosti u Dalmaciji, 21 (1980.), 215-224; NIKOLA JAKŠIĆ (bilj. 11), 53-66.

25

DRAGUTIN KNIEWALD, Antependij i pala stolne crkve u Krku, u: Godišnjak Sveučilišta Kraljevine Jugoslavije u Zagrebu, 1924/25. - 1928/29. (1929.), 49-57; MILAN PELC (bilj. 19), 415; DANIJEL CIKOVIĆ (bilj. 16). Koristim priliku zahvaliti kolegi Cikoviću na nesebičnoj pomoći i razgovoru u vezi s krčkom srebrnom palom.

26

IVAN MATEJČIĆ, Antependio argenteo dell'altare maggiore della cattedrale di Parenzo, u: Ars auro gemmisque prior. Mélanges en hommage à Jean-Pierre Caillet, (ur.) Christelle Blondeau i dr., Zagreb - Motovun, 2013., 395-405; DANIJEL CIKOVIĆ, Arhivske novosti o srebrnoj pali Eufrazijeve bazilike, u: Istra u novom vijeku. Monografije i katalozi, 30, (ur.) Tatjana Bradara, Pula, 2017., 65-79.

27

GIOVANNI LUCIO, Memorie istoriche di Tragurio ora detto Traù, 1674., 490. Slično izvještava i biskup Didak Manola u vizitaciji trogirske biskupije: "Super ipsum armadium vetus vidit duas tabulas pictas (...) Imagines ipsarum tabularum diebus solemnibus ornabantur, et coopernibantur argenteis laminibus; et de anno 1424 perspexit in administatione, quod Nicolaus Michaelis Silvestri operarius expendavit L. 2 pro mundanda argentea pala Altaris majoris. «, prijepis prema: RADOSLAV TOMIĆ, Trogirska slikarska baština od 15-20. stoljeća, Zagreb - Split, 1997., 17-20. 
28

JOŠKO BELAMARIĆ (bilj. 19), 18; RADOSLAV TOMIĆ (bilj. 27), 17-20.

\section{9}

»Icon est argento circum quod ordinavit mutari tabulas et ipsas depingi cum sint vetusta.«, Visitatio apostolica spalatensis 1603 Michaelis Priolo. Archivio Secreto Vaticano. Miscellanea Arm. VII no. 100. Prijepis prema: CVITO FISKOVIĆ (bilj. 12), 95, bilj. 34.

30

Više u: IVANA PRIJATELJ PAVIČIĆ (bilj. 20), 167.

31

Svoju hipotezu Ciković temelji na podudarnim dimenzijama Fedrigazzijevih slika s onima porečke srebrne pale te ikonografijom svetaca koju slikar preuzima s pale; DANIJEL CIKOVIĆ (bilj. 16), 22; ISTI (bilj. 26) 65-79.

32

VIŠNJA BRALIĆ, Kat. 255: Sv. Mauro s modelom grada; Kat. 256: Sv. Eleuterije, u: Slikarska baština Istre: djela štafelajnog slikarstva od 15. do 18. stoljeća na području Porečko-pulske biskupije, (ur.) Višnja Bralić i Milan Pelc, Zagreb, 2006., 331-332; ISTA, I dipinti ritrovati della cattedrale parentina, u: Saggi e memorie di storia dell'arte, 30 (2008.), 163-179; RADOSLAV TOMIĆ, Slikar Giovanni Francesco Fedrigazzi u Dalmaciji, u: Radovi Instituta za povijest umjetnosti, 37 (2013.), 113-128.

\section{3}

"Diebus ferialibus praedicta Palla clauditur ligneis portulis intus et foris Sanctorum imaginibus ornatis et in tella pictis quae stant pro palla. Sed cum presentes sint multum vetustate lacerae et indecentes ordinavit Dominatio Sua ut quam primum provideatur de novis Portulis convenientibus et Pictura ornatis vel de convenienti sacro conopeo in quo expressa et picta appareat imago Sancti Tryphonis taliter aptata ut et claudere et aperire valeat altare nec non a pulvere reparare...«, prijepis prema IVO STJEPČEVIĆ, Arhivska istraživanja Boke Kotorske, Perast, 2003., 31, 88.

\section{4}

DANIEL FARLATI, Illyrici sacri tomus tertius. Ecclesia spalatensis olim salonitana, Venecija, 1775., 466-467, De visitatione Apostolica Dalmatiae Véneta Augustino Valerio Episcopo Veronensi commissa (Decretum de novo choro condento). O gradnji kora vidi: GORAN NIKŠIĆ, Kor splitske katedrale, u: Prilozi povijesti umjetnosti u Dalmaciji, 40 (2003.-2004.), 263-305.

\section{5}

Žana Matulić Bilač svoju hipotezu o dimenzijama pale temelji na širini niše svetišta katedrale u vrijeme njezine izrade te u odnosu na hipotetsku rekonstrukciju srebrne pale s oltara sv. Dujma čiji su se fragmenti sačuvali do danas. ŽANA MATULIĆ BILAČ (bilj. 5, 2014.), 280, bilj. 36; ISTA (bilj. 5, 2016.), 54.

\section{6}

Svetište je prije višekratnih širenja bilo široko 345 centimetra, a nakon širenja 474 centimetra. Faze širenja i produbljenja svetišta donosi ŽANA MATULIĆ BILAČ (bilj. 5, 2016.), 54.

37

ARSEN DUPLANČIĆ (bilj. 2), 319.

38

DANIJEL CIKOVIĆ (bilj. 16), 10, bilj. 44.

39

DANIJEL CIKOVIĆ (bilj. 26), 54.

40

IVANA PRIJATELJ PAVIČIĆ (bilj. 20), 164.
41

Trogirska je pala po svoj prilici bila nešto manja od ostalih, $\mathrm{s}$ obzirom na to da su dimenzije pale feriale $200 \times 90 \mathrm{~cm}$.

42

ARSEN DUPLANČIĆ (bilj. 2), 318-319.

43

GIUSEPPE PRAGA, Antichi inventari del tesoro di san Doimo di Spalato, u: Archivio Storico per la Dalmazia, 20 (1935.), 10.

44 ARSEN DUPLANČIĆ (bilj. 2), 319, bilj. 78.

45 DEŠA DIANA - NADA GOGALA - SOFIJA MATIJEVIĆ, Riznica splitske katedrale, Split, 1972., 20-21.

46

ARSEN DUPLANČIĆ (bilj. 2), 314.

47

»Vidit quoque argenta fracta antiquata et inutilia, praecipue iconem olim altaris maioris, que in duas divisas partes complicatur habens sanctorum figuras ex lamina argentea; opus antiquum ac rudis artificis; quorum pleraque posse melius converti in candelabra et vasa decentia, ad ornamentum ecclesiae et altarium.", prijepis prema: KRUNO PRIJATELJ (bilj. 10, 1995.), 86.

48

KRUNO PRIJATELJ (bilj. 1, 1974.), 19, bilj. 10; ŽANA MATULIĆ BILAČ (bilj. 5, 2016.), 53.

49

VLADIMIR MARKOVIĆ (bilj. 1), 136.

50

VLADIMIR MARKOVIĆ (bilj. 1), 76.

51

Ciklus se sastoji od osam slika. Dva para slika u donjoj zoni lučnoga svoda nemaju perspektivno skraćenje, jer su bliže promatraču, dok su dva para prema tjemenu luka drukčije perspektivno zasnovana.

52

RADOSLAV TOMIĆ (bilj. 1), 121.

53

Isto, 129-131.

54

O bratovštini Presvetog Tijela Kristova u Splitu vidi: IVAN OSTOJIĆ, Stara bratovština Presvetog Tijela Kristova u Splitu, u: Bogoslovska smotra, 45, 4 (1976., siječanj), 479-488; ISTI, Stara bratovština Presvetog Tijela Kristova u Splitu, u: Bogoslovska smotra, 46, 3 (1977., siječanj), 310-323.

55

To je djelomično ispravno uočila Matulić Bilač u svojoj hipotetskoj rekonstrukciji dvaju poliptiha. Usp.: ŽANA MATULIĆ BILAČ (bilj. 5, 2016.), 66.

56

Više o kolekcijama egzempla u: JACQUES DE VITRY, The Exempla or Illustrative Stories from the Sermones Vulgares of Jacques de Vitry, (prir.) Thomas Frederick Crane, London, 1878.

57

Takvu rasporedu jedino ne odgovara predzadnji par u kojemu su po svoj prilici pogreškom zamijenjene pozicije.

58

MIRI RUBIN, Corpus Christi. The Eucharist in Late Medieval Culture, Cambridge, 1991., 108-109; CATHERINE HARDING, 
Speaking pictures: cognition, spiritual understanding and the decoration of the Chapel of the Corporal at Orvieto Cathedral, u: Spazi e Immagini dell'Eucharistia, (ur.) Gianni Cioli i dr., Bologna, 2007., 246.

\section{9}

\section{CATHERINE HARDING (bilj. 58), 247.}

60

PAUL H. D. KAPLAN, The Paliotto of the Corpus Domini: a Eucharistic Sculpture for a Venetian Nunnery, u: Studies in Iconography, 26 (2005), 121-174.

61

Leksikon ikonografije, liturgike i simbolike zapadnog kršćanstva, (ur.) Anđelko Badurina, Zagreb, 1985., 400-401.

62 MIRI RUBIN (bilj. 58), 130-131.

63 Biblija, Ps 100 (109): 4, Hrvatsko biblijsko društvo Zagreb, Zagreb, 2013., 682. O značenju toga psalma razvile su se opsežne teološke rasprave između Židova i kršćana tijekom 2. stoljeća.; BARBARA MARIA SAVY, Manducatio per visum, Temi eucharistici nella pittura di Romanino e Moretto, Citadella, 2006., 71, bilj. 145.

64

Biblija, Heb 7: 17 (bilj. 63), 1327.

65

WILLIAM WHITAKER - WILLIAM FITZGERALD, A Disputation on Holy Scripture: Against the Papists, Especially Bellarmine and Stapleton, Cambridge, 1849., 167-168; MAURICE E. COPE, The Venetian Chapel of the Sacrament in the Sixteent Century, New York - London, 1979., 220; BARBARA MARIA SAVY (bilj. 63), 54.

66

MAURICE E. COPE (bilj. 65), 188-189.

67

Biblija, Iv 6, 49-51 (bilj. 63),1196.

68

Biblija, Izl 16:33,34 (bilj. 63), 67.

69

Biblia sacra: vulgatae editionis, Liber Exodi, 16:33,34, Parisiis, 1891, 84.

70

Više o vezi ikonografije splitskog thronuma glavnoga oltara s kovčegom zavjeta i Ponzonijevim slikama koje su u njega umetnute: DANIEL PREMERL, Glavni oltar splitske katedrale, tipologija, ikonografija i hipoteza o naručitelju, u: Sic Ars deprenditur arte, Zbornik u čast Vladimira Markovića, (ur.) Sanja Cvetnić, Milan Pelc, Daniel Premerl, Zagreb, 2009., 429-430.

71

Biblija, $\operatorname{Br} 13$ (bilj. 63), 140-141.

72

Leksikon (bilj. 61), 318.

73

O zapovjednim gestama vidi prvo poglavlje u: CHIARA FRUGONI, La voce delle immagini. Pillole iconografiche dal Medioevo, Torino, 2010., 3-48.

74

LUIS M. GIRÓN-NEGRÓN, Weeping Over Rachel's Tomb: Literary Reelaborations of a Midrashic Motif in Medieval and Early Modern Spain, u: The Hebrew Bible in Fifteenth-Century
Spain: Exegesis, Literature, (ur.) Jonathan Decter, Arturo Prats, Leiden - Boston, 2012., 35-36.

75

PAUL HAFFNER, The Sacramental Mystery, Wiltshire, 1999., 77.

76

MAURICE E. COPE (bilj. 65), 72; SANJA CVETNIĆ, Ikonografija nakon Tridentskog sabora i hrvatska likovna baština, Zagreb, 2007., 155.

77

CHIARA FRUGONI, Una Solitudine Abitata, Chiara d'Assisi, Rim - Bari, 2006., 68-69.

78

Zanimljiv je tekst propovijedi humanista Baldassarea Bonifaccia, biskupa Kopra u Istri, koju je tiskao u Veneciji 1657. godine. Propovijed koja veliča sv. Klaru nalazi se u dijelu posvećenu papi Aleksandru VII., a izrečena je u crkvi sv. Klare u Veneciji u povodu pobjede Venecije nad Osmanlijama u Egejskom moru. U svojoj propovijedi Baldassare je izjavio da je trijumf sv. Klare nad Saracenima istovjetan pobjedi Venecijanaca nad Osmanlijama na Peloponezu. - Citirano prema: NIRIT BEN-ARYEH DEBBY, St. Clare Expelling the Saracens from Assisi: Religious Confrontation in Word and Image, u: The Sixteenth Century Journal. The Journal of Early Modern Studies, 43, 3 (2012.), 644.

79

Patrologiae cursus completus: sive biblioteca universalis,integra uniformis, commoda, oeconomica, omnium SS. Patrum, doctorum scriptorumque eccelesiasticorum qui ab aevo apostolico ad usque Innocentii III tempora floruerunt ... [Series Latina, in qua prodeunt Patres, doctores scriptoresque Ecclesiae Latinae, a Tertulliano ad Innocentium III], Petit-Montrouge, 1849; 301.

80

LEAH SINANOGLOU, The Christ Child as Sacrifice: A Medieval Tradition and the Corpus Christi Plays, u: Speculum, 48, 3 (1973.), 493; LEAH S. MARCUS, The Christ Child as Sacrifice: A medieval Tradition and the English Cycle Plays, u: The Christ Child in Medieval Culture: Alpha es et O! (ur.) Mary Dzon i Theresa M. Kenney, Toronto - Buffalo -ondon, 2012, 5.

81

The »Summa Theologica « of St. Thomas Aquinas, part III, Third number (qq. LX-LXXXIII), London, 1914, 301-304.

82

LEAH SINANOGLOU (bilj. 80), 491-509; LEAH S. MARCUS (bilj. 80), 5 .

83

The Ecclesiastical History of Evagrius Scholasticus, (preveo i prir.) Michael Whitby, Liverpool, 2000, 241-242.

84

GREGORY OF TOURS, Glory of the Martyrs, preveo i priredio Raymond van Dam, Liverpool, 1988., 29-31.

85

GREGORY OF TOURS (bilj. 84).

86

Isto, 29-31; MIRI RUBIN, Gentile Tales, The Narrative Assault on Late Medieval Jews, Philadelphia, 1999., 8-9.

87

Za kronološki pregled recepcije ove priče vidi: EUGENIUS WOLTER, Der Legende vom Judenknaben, Halis Saxonum, 1879.; THEODOR PELIZAEUS, Beiträge zur Geschichte der 
Legende vom Judenknaben, Inaugural-Dissertation, Haale a.d. Saale, 1914.; THEODOR NISSEN, Zu den ältesten Fassungen der Legende vom Judenknaben, u: Zeitschrift für französische Sprache und Literatur, 62, H. 7/8 (1939.), 393-403; MIRI RUBIN (bilj. 86), 8-23; PAMELA A. PATTON, The Little Jewish Boy: Afterlife of a Byzantine Legend in Thirteenth-Century Spain, u: Byzantine Images and their Afterlives: Essays in Honor of Annemarie Weyl Carr, (ur.) Lynn Jones, London - New York, 2016., 61-80.

88

Les Miracles de Nostre Dame par Gautier de Coincy, (prir.) Frédéric Kœnig, Genève, 1955.

\section{9}

Kolekcija nije bila ilustrirana za života Gautiea de Coincija već su po svoj prilici najraniji ilustrirani manuskripti oni koji datiraju iz 1250-1260. godine pa nadalje. Usp.: FUENSANTA MURCIA NICOLÁS, Milagro e imágenes de culto. Una nueva cultura visual en los manuscritos de Gautier de Coinci, u: Codex Aquilarensis, 28 (2012.), 169-184.

90

Zbirku je kompilirao negdje oko 1308.-1310. godine dominikanac Arnold de Liège, a do danas je sačuvano i poznato više od pedeset sačuvanih kopija. Našu temu pronalazimo pod nazivom Eukaristia sumpta ab infideli a combustione eum protexit. An Alphabet of Tales. An English $15^{\text {th }}$ century translation of the Alphabetum Narrationum of Etienne de Besançon, (prir.) Mary Macleod Banks, Vol. I, London, 1904.-1905., 210-211;

JACQUES LE GOFF, L'ebreo negli exempla medievali: il caso dell' Alphabetum Narrationum, u: Il meraviglioso e il quotidiano nell'Occidente medievale, (ur.) Francesco Maiello, Roma - Bari 1983.,145-163.

\section{1}

Priča o židovskom dječaku zabilježena je pod naslovom: Un putto hebreo in compania di alcuni fanciulli christiani prende la santa communione, e per cio messo dal padre in una fornace ardente, $e$ liberato dalla Vergine. Usp: SERAFINO RAZZI, Miracoli Di Nostra Donna, Raccolti Nuovamente, Firenze, 1576., 26-27.

92

MONTAGUE RHODES JAMES - ERNEST WILLIAM TRISTRAM, The Wall Paintings in Eton College Chapel and In The Lady Chapel of Winchester Cathedral, $\mathrm{u}$ : The Volume of the Walpole Society, 17 (1928.-1929.), 1-43; MIRI RUBIN (bilj. 86), 18.

93

LUIGI FUMI, Il duomo di Orvieto e i suoi restauri; monografie storiche condotte sopra i documenti, Roma, 1891., 364.

94

Isti je prizor naslikao Stefano da Ferrara oko 1350. godine u kapeli Dell' Arca u bazilici sv. Ante u Padovi, ali se freske nisu sačuvale.

95

Primjerice Liber exemplorum fratrum Minorum saeculi XIII. Usp.: LIVARIUS OLIGER, Liber exemplorum fratrum Minorum saeculi XIII, u: Antonianum, 2 (1927.), 214.

96

"Exemplum de heretico qui docuerat asinum suum comedere hostias non consecratas, qui quadam die disputans cum quodam sacerdote de Corpore Christi dixit: Quid dicitis de vestro Corpore Christi? Asinus meus comederet milia talia Corpora, si darentur ei. Qui sacerdos: Certe mentiris, quia Corpus Christi non est cibus asinorum sed animarum. Quid faciamus bene? Ego portabo illud asino tuo, et si comederet, ego volo credere quod credis, et si non comederit, crede tu quod credo. Tunc hereticus gaudens concessit ei. Portavit ergo sacerdos fidenter Corpus Christi ad asinum coram multis et cum fuit prope asinum, ille statim flexit genua ei et cepit fortiter lacrimari et ita fecit donee sacerdos illud ad ecclesiam reportavit. Quod videns hereticus, conversus est ad fidem (...)« - LIVARIUS OLIGER (bilj. 96), 214.

97

Zoran je primjer slika (antependij) neznanog autora iz 1315. godine, podrijetlom iz mjesta Tamarite de Literas, koja se danas čuva u Barceloni u Museu Nacional d’Art de Catalunya.

98

MARISA MELERO-MONEO, Eucaristía y polémica antisemita en el retablo y frontal de Vallbona de les Monges, u: Locvs Amoenvs, 6 (2002.-2003.), 21-40; MARÍA LUISA MELERO MONEO, La pintura sobre tabla del gótico lineal, Frontales, laterales de altar y retablos en el reino de Mallorca y los condados catalanes, Ballaterra, Barcelona - Girona - Lleida, 2005., 176-180.

99

PAUL H. D. KAPLAN (bilj. 60), 121-174.

100

SANJA CVETNIĆ (bilj. 76), 155.

101

IVAN ARMANDA, Splitski nadbiskup i teološki pisac Bernard iz Perugie, u: Kulturna baština, 37 (2011.), 33-48.

102

VLADIMIR PETER GOSS, Četiri stoljeća europske umjetnosti 800.-1200. Pogled s jugoistoka, Zagreb, 2010., 110.

103

Osvojivši tvrđavu Klis, nadomak Splita, Osmanlije su na tom prostoru od 1537. godine do njihova izgona 1648. godine, pa su bili stvarna i svakodnevna prijetnja za grad, koja se nastavila sporadično i u drugoj polovici 17. stoljeća. GRGA NOVAK, Prošlost Dalmacije, Split, 2004., 15.

104

KRUNO PRIJATELJ, Marginalije o nadbiskupu Markantunu De Dominisu i braći nadbiskupu Sforzi i slikaru Mateju Ponzoniju, u: Kulturna baština, 22-23 (1993.), 51.

105

LOVORKA ČORALIĆ, Hrvati u procesima Mletačke inkvizicije (prvi dio), u: Croatica Christiana periodica, 19, 36. (1995.), 19-68; FRANJO ŠANJEK, Markantun de Dominis i Inkvizicija, Rijeka, 2011., 27-30.

106

LOVORKA ČORALIĆ, Dalmatinski »protestanti« Dominisova doba - tragom procesa Mletačke inkvizicije (16.-17. st.), u: Marko Antun de Dominis, splitski nadbiskup, teolog i fizičar. Zbornik radova sa znanstvenog skupa održana 16. do 18. rujna 2002. godine u Splitu, (ur.) Vesna Tudjina, Split, 2006., 279.

107

LOVORKA ČORALIĆ, Hrvati u procesima Mletačke inkvizicije (drugi dio), u: Croatica Christiana periodica, 20, 37 (1996.), 25, 30; ISTA (bilj. 106), 279.

108

GRGA NOVAK, Hereza Agostina Capogrossa, "protestanta « Splićanina, u: Zgodovinski časopis, 6-7, (1952.-1953.), 596-603. O procesu protiv Agostina Capogrossa i svjedocima sudionicima istrage vidi i: IVAN OSTOJIĆ, Metropolitanski kaptol u Splitu, Zagreb, 1975., 184, 208-209, 224, 258, 261, 263, 265-266.

109

GRGA NOVAK (bilj. 108), 598. 
110

VID MORPURGO, Nadbiskup splitski i njegov jevrejski liječnik, u: Jevrejski glas, 24. travnja 1929.

111

MARKO JAČOV, Spisi tajnog vatikanskog arhiva XVI - XVIII veka, Beograd, 1983., 55.

112

O kodificiranim atributima inovjernika i načinu njihova distingviranja od kršćana postoji zavidna količina literature. Spomenut ćemo samo neke naslove koji su poslužili u istraživanju za ovaj tekst: RUTH MELLINKOFF, Outcasts, Signs of otherness in Northern European art of the late Middle Ages, Berkeley, 1993; BERNHARD BLUMENKRANTZ, Il Cappello a punta. L' ebreo medievale nello specchio dell'arte christiana, RomaBari, 2003.; GIUSEPPE CAPRIOTTI, Lo scorpione sul petto. Iconografia antiebraica tra XV e XVI secolo alla periferia delo Stato Pontificio, Roma, 2014.: FABIO TONZAR, Genti diverse.
L'iconografia degli "altri" nell'arte triveneta dei secoli XI-XIV, doktorska disertacija, Udine, 2013.-2014.; JOYCE KUBISKI, Orientalizing Costume in Early Fifteenth-Century French Manuscript Painting (Cité des Dames Master, Limbourg Brothers, Boucicaut Master, and Bedford Master), u: Gesta, 40, 2, (2001.), 161-180; SANJA CVETNIĆ, Osmanska vojska i politička ikonografija u 17. i 18. stoljeću u kontinentalnoj Hrvatskoj, u: Peristil, 53 (2010.), 153-160.

113

FABIO TONZAR (bilj. 112), 83.

114

Isto, 83 .

115

PIERRE CHAUNU, Vrijeme reformi. Religijska historija i civilizacijski sistem, Zagreb, 2002., 184.

\section{Ten Paintings by Matteo Ponzone above the Main Altar of the Split Cathedral: Considerations on Design and Style, the Original Function, and the Iconographic-Iconological Aspect}

So far, art historians have generally accepted the Venetian painter Matteo Ponzone (b. 1583 in Venice - d. 1663/1675) as the author of ten paintings located in the vault above the main altar of the Split Cathedral. There is also a consensus in art criticism that the paintings were probably made between 1635 and 1640, and that at the time of Cosmi's interventions in the cathedral, probably between 1682 and 1689, they were moved to the gilded cassette vault, where they are still seen today. However, the form of the original pictorial ensemble, its purpose, and its location within the Split Cathedral have been a matter of debate, given that the paintings preceded the construction of the wooden vault for almost fifty years. The iconographic and iconological aspects of the individual episodes as well as their overall interpretation in the context of the time of their creation have so far been barely considered beyond the brief descriptions of individual scenes, identified by Kruno Prijatelj back in the 1970s, after their restoration.

Based on the material finds and the interpretation of published archival data, the author suggests a hypothesis about the original form of the pictorial ensemble as a single polyptych, with two horizontal registers of symmetrically arranged images, which served as the cover altarpiece (pala feriale) for the large silver Gothic altarpiece by Iohannes Gerardini de Pesaro. Such a painted cover was permanently exposed and visible on the altar, and would only be removed or opened during important ceremonies and on special days in the Church calendar to allow for a glimpse of the silver and gilded altarpiece that otherwise remained concealed to the public. This concept of altarpiece has here been compared with similar examples from Venice. The most famous example is the pala feriale painted between 1343 and 1345 by Venetian painter Paolo Veneziano in collaboration with his sons, as a cover for the altarpiece made of noble metals in the basilica of St Mark, known as the Pala d'oro. The lagoon town seems to have had a dozen altarpieces made of noble metals, of which only three have remained preserved to the present day, and all, without exception, had a pala feriale. The hypothesis on the features of design and style in the Split altarpiece has also been corroborated by analogies with similar examples from the Eastern Adriatic (Poreč, Krk, Trogir, Kotor...), as their descriptions have been preserved in reports of episcopal visitations.

The article also analyses the iconographic-iconic aspect of the painting cycle, originally consisting of a sequence of Old Testament scenes, in which the central axis would be a painting depicting the Last Supper. Its counterpart in the central axis of the upper row would be the painting showing Christ whose blood is gathered by the angels, flanked on both sides by paintings whose common iconographic backbone should be considered as Eucharistic exempla. In this way, the selected subjects from the Old Testament would have prefigured the doctrine of transubstantiation and consequently a series of Eucharistic exempla - illustrative, didactic stories whose task was to teach and consolidate the mystery of the Eucharist by mediating sermons and visually rendered miracles. They were largely derived from medieval literary and visual narra- 
tives, and commonly involved a consecrated host playing the key role in miraculous events, and the inevitable presence of marginalized groups in the medieval society: Jews, women, heretics, or clergy in need of additional teaching. Thus, the entire arrangement is a sort of treatise on the Eucharist done in the painting medium, which directly relies on the medieval concepts of Biblia pauperum, Speculum Humanae Salvationis or even more on the allegorical concept of Bible Moralisée, which all use visual and textual correlations between the Old and New Testaments, that is, between people and events from the Biblical world on the one side, and people and events in the medieval world on the other. This revival of medieval themes and concepts in the post-Tridentine restoration of the Church has here been linked to a crisis within the Catholic Church and the emergence of heresy and Protestantism within the metropolitan Church of Split. The dogmatic issue of transubstantiation, especially in relation to Luther and the Reformers who rejected the belief that Christ was present in the Eucharist in the Catholic sense, was solved by resorting to an "external enemy". This was aptly found in the Jews in the collections of exempla and their visual narratives, which in the $17^{\text {th }}$ century become a metonymy for the Protestant identity, since both rejected the belief in transubstantiation and every manifestation of the actual presence of Christ's body in the host, and since the Protestants did not have special external features to identify them in artworks.

Keywords: Split, painting, Matteo Ponzone (Ponzoni, Pončun), Sforza Ponzone (Ponzoni), Middle Ages, exempla, $17^{\text {th }}$ century, iconography, iconology, Eucharist, Protestantism 


\section{Izvori ilustracija i autori fotografija / Sources of illustrations and photo Credits}

\begin{abstract}
Laura Chinellato
Le lastre longobarde del »pulpito di Maviorano« di Gussago (Brescia): dall' analisi al contesto. Problematicità e nuove prospettive / Langobardske ploče "Mavioranove propovjedaonice « u Gussagu (Brescia): od analize do konteksta. Problematika i nove perspektive

1: Elaborazione grafica di Laura Chinellato da: Paola Marina De Marchi, Calvisano e la necropoli d' ambito longobardo in località Santi di Sopra. La pianura tra l'Oglio, Mella e Chiese nell'altomedioevo, in: L'Italia centro-settentrionale in età longobarda, Atti del Convegno (Ascoli Piceno, 6-7 ottobre 1995), (a cura di) Lidia Paroli, Firenze, 1997., 377-411, fig. 2 / Ilustraciju iz članka: Paola Marina De Marchi, Calvisano e la necropoli d' ambito longobardo in località Santi di Sopra. La pianura tra l'Oglio, Mella e Chiese nell'altomedioevo, in: L'Italia centro-settentrionale in età longobarda, Atti del Convegno (Ascoli Piceno, 6-7 ottobre 1995), (a cura di) Lidia Paroli, Firenze, 1997., 377-411, 2, grafički obradila Laura Chinellato.

2: Studio Rapuzzi di Brescia

3, 4, 5, 6, 7, 8, 10: Laura Chinellato

9: Bruno Genito, Sasanidi, u: Enciclopedia dell'Arte Medievale, X, Roma, 1999., 381-386.
\end{abstract}

\section{Danko Zelić - Ivan Viđen}

Inventario dela giexia di S. Maria Mazor, de tute le argentarie, aparati deli sazerdoti, insenarii, libri, tapezarie et altre robe (1531.) - najstariji imovnik liturgijske opreme, ruha i paramenata dubrovačke prvostolnice / Inventario dela giexia di S. Maria Mazor, de tute le argentarie, aparati deli sazerdoti, insenarii, libri, tapezarie et altre robe (1531) - the Oldest Extant Inventory of Liturgical Objects, Vestments and Textiles of Dubrovnik Cathedral

1: Danko Zelić

2, 3: Božo Gjukić

\section{Josipa Alviž}

Sudbina kapucina i kapucinskoga hospicija u Herceg Novom u svjetlu novih arhivskih istraživanja / The Capuchins and their Hospice in Herceg Novi in the Light of Recent Archival Research

1, 2: Državni arhiv u Zadru (DAZD) / State Archives in Zadar 3, 5, 6, 8-10, 12: Josipa Alviž

4, 7, 11: Arhitektonski crteži prema nacrtima Direkcije za urbanizam Herceg Novi, urbanistički projekt Stari Grad - Herceg Novi, 1982., voditelj Boris Ilijanić, dipl. ing. arh. Izvor: Državni arhiv Crne Gore - Arhivski odsjek Herceg Novi, za tisak pripremio Ratko Horvat I Architectural drawings made after recording of the Directorate for Urban Planning Herceg Novi, Stari Grad - Herceg Novi urban development project, 1982, project leader Boris Ilijanić, architect. Source: State Archives of Montenegro - Archival Department Herceg Novi, prepared by Ratko Horvat

\section{Bojan Goja}

Kuća Dragičević: prilog poznavanju stambenih kuća u Zadru u 18. stoljeću / The Dragičević House: A Contribution to the Research on the $18^{\text {th }}$-century Houses in Zadar

\section{1-9: Bojan Goja \\ 10: Google Earth}

\section{Petar Puhmajer - Krasanka Majer Jurišić}

Stara gradska vijećnica u Rijeci: povijest sjedišta gradske vlasti od najranijih zapisa do 19. stoljeća / Old Town Hall in Rijeka: History of the City Council Seat from the Earliest Records to the $19^{\text {th }}$ Century

1, 11, 12, 13: Natalija Vasić, Hrvatski restauratorski zavod

2: Silvino Gigante, Storia del comune di Fiume, Fiume, 1913.

3: Österreichische Nationalbibliothek, Cod. 8607, fol. 3r, Fiume 4: Österreichisches Staatsarchiv, Kriegsarchiv, Kartensammlung, sign. AT-OeStA/KA KPS KS G I h,171

5: Matthäus Merian: Topographia provinciae Austriacarum, izdanje 1679.

6: Österreichisches Staatsarchiv, Kriegsarchiv, Kartensammlung, sign. AT-OeStA/KA KPS KS G I h, 175

7a, 7b: Državni arhiv u Rijeci, Gradski magistrat Rijeka, Izdvojeni nacrti, kut. 284

8: Državni arhiv u Rijeci, Tehnički ured grada Rijeke, kut. 161

9: Konzervatorski odjel u Rijeci, fototeka

10, 14: Izradili Petar Puhmajer i Marin Čalušić, Hrvatski restauratorski zavod, 2017.

\section{Sanja Cvetnić}

Dva portreta Beatrice Frankapan (?): rod i red / Two Portraits of Beatrice Frankapan (?): the Family and the Order

1: Ivan Kukuljević Sakcinski, Beatrica Frankapan i njezin rod. Zagreb [s. e. Tiskom Dioničke tiskare], 1885.

2: Adolf Bayer, Markgraf Georg und Beatrix von Frangepan: Georg des Frommen Jugend und erste Ehe, Gesellschaft für Fränkische Geschichte, u: Neujahrsblätter der Gesellschaft für Fränkische Geschichte, Ansbach: Brügel, 19 (1934.)

3: (C) Madrid, Museo Thyssen-Bornemisza

4: () Graz, Universalmuseum Joanneum Schloss Eggenberg \& Alte Galerie

5, 6: ๑ Zagreb, Hrvatski državni arhiv

7: ( ) Klagenfurt, Landesmuseum Kärnten

8: Anton Fritz, Das große Hemma-Buch, 1980.

\section{Júlia Tátrai}

Wiener Hofkünstler und die Zrínyis. Porträts in der Lobkowicz-Sammlung / Bečki dvorski umjetnici i Zrinski. Portreti u Zbirci Lobkowicz 
1: 도 Nelahozeves, Lobkowicz Sammlung, Schloss Nelahozeves / Bridgeman Images

2, 3: () Budapest, Magyar Nemzeti Múzeum (Ungarisches Nationalmuseum)

4: ( ) Trakošćan, Dvorac Trakošćan (Schloss Trakošćan)

5: (C) Nelahozeves, Lobkowicz Sammlung, Schloss Nelahozeves / Bridgeman Images

6: @ Budapest, Magyar Nemzeti Galéria (Ungarische Nationalgalerie)

7: @ Zagreb, Hrvatski državni arhiv (Kroatisches Staatsarchiv)

8: () Nelahozeves, Lobkowicz Sammlung, Schloss Nelahozeves /

Bridgeman Images

9: () Privatbesitz Familie Herberstein

10: () Wien, Kunsthistorisches Museum, Wien

11: () Prag, Lobkowicz Sammlung, Prag / Bridgeman Images

12: ๑ Budapest, Magyar Nemzeti Galéria (Ungarische Nationalgalerie)

\section{Daniel Premerl}

Ivan Tomko Mrnavić and his Coat of Arms: Self-presentation of an Illyrian Noble / Ivan Tomko Mrnavić i njegov grb: samopredstavljanje jednoga ilirskoga plemića

1, 2: Paolo Mofardin, Institute of Art History, Zagreb; Courtesy of the Metropolitan Library, Zagreb / Institut za povijest umjetnosti, Zagreb; Uz dopuštenje Metropolitanske knjižnice, Zagreb

$3,6,14,15,16,17$ : Courtesy of the National and University Library, Zagreb / Uz dopuštenje Nacionalne i sveučilišne knjižnice, Zagreb

4, 5: Paolo Mofardin, Institute of Art History, Zagreb; Courtesy of the Library of the Croatian Academy of Sciences and Arts / Institut za povijest umjetnosti, Zagreb; Uz dopuštenje Knjižnice Hrvatske akademije znanosti i umjetnosti

7, 8: Courtesy of the Research Library Zadar / Uz dopuštenje Znanstvene knjižnice Zadar

9: Fra Stipe Nosić, the Library of the Franciscan Monastery, Dubrovnik / Knjižnica Male braće, Dubrovnik

10: Tomislav Pavičić, City Museum Šibenik / Tomislav Pavičić, Muzej Grada Šibenika

11, 12: Paolo Mofardin, Institute of Art History, Zagreb; Courtesy of the Archdiocesan Archives, Zagreb / Institut za povijest umjetnosti, Zagreb; Uz dopuštenje Nadbiskupijskog arhiva, Zagreb

13: Courtesy of the Archives of the Croatian Academy of Sciences and Arts, Zagreb / Uz dopuštenje Arhiva Hrvatske akademije znanosti i umjetnosti, Zagreb

\section{Ivana Čapeta Rakić}

Ponzonijevih deset slika u svodu glavnog oltara splitske katedrale: razmatranja o stilsko-oblikovnim svojstvima, izvornoj funkciji i ikono- grafsko-ikonološkom aspektu / Ten Paintings by Matteo Ponzoni above the Main Altar of the Split Cathedral: Considerations on Design and Style, the Original Function, and the Iconographic-Iconological Aspect

\section{1, 2: Ivana Čapeta Rakić}

3: Ivana Čapeta Rakić, rekonstrukcija / reconstruction: Vojan Koceić 4: Mirko Pivčević, rekonstrukcija / reconstruction: Vojan Koceić

5: Uz dopuštenje Fondazione Musei Civici di Venezia / Courtesy of the Fondazione Musei Civici di Venezia

6: Fotografija preuzeta sa službene web stranice muzeja www.museunacional.cat, uz dopuštenje za preuzimanje i objavu fotografije od muzeja Museu Nacional d'Art de Catalunya / Photo from the official website of the museum, www.museunacional.cat (courtesy of the Museu Nacional d'Art de Catalunya)

\section{Renata Komič Marn}

Saint Joseph and Baby Jesus by Valentin Metzinger and Other Paintings from the Strahl Collection in the Museum of Arts and Crafts in Zagreb / Slika Sveti Josip s malim Isusom Valentina Metzingera $i$ druge slike iz Zbirke Strahl u Muzeju za umjetnost i obrt u Zagrebu

1, 3-6: Srećko Budek i Vedran Benović, Muzej za umjetnost i obrt / Museum of Arts and Crafts, Zagreb, digitalne snimke predmeta iz muzejskog fundusa

2: Ljudevit Griesbach, HAZU, Strossmayerova galerija starih majstora, Zagreb / Croatian Academy of Sciences and Arts, Strossmayer Gallery of Old Masters, Zagreb

\section{Jasminka Najcer Sabljak}

Prizori iz Slavonije i Srijema u opusu austrijskog slikara Franza Alta I Scenes from Slavonia and Syrmia in the Opus of Austrian Painter Franz Alt

\section{1, 9: Georg Eltz}

2, 4-8: Francisca Clary-Aldringen

3: Arhiv Zavičajnog muzeja Ruma / Archive of the Ruma County Museum

\section{Ana Šeparović}

Od »sinteze likovnih umjetnosti« do Zagrebačkoga salona: prilog poznavanju djelovanja ULUH-a 1960-ih / From a "Synthesis of Visual Arts" to the Zagreb Salon: A Contribution to the Research on ULUH's Activity in the 1960s

1: Socijalizam i modernost, katalog izložbe, Zagreb, 2012., 141. 